\title{
Students' Problem-solving Difficulties and Coping Strategies in Mathematics: A Model- Building Study
}

\author{
Dinah C. Vidad* \\ Mariano Marcos State University, Batac City, Ilocos Norte, Philippines \\ https:// orcid.org/0000-0002-8730-2436 \\ Maria Ana T. Quimbo \\ University of the Philippines, Los Baños, Laguna, Philippines \\ https://orcid.org/0000-0002-0797-6204
}

\begin{abstract}
A number of research projects in educational assessment reveal that students struggle when it comes to accomplishing problem-solving tasks in Mathematics. Such a struggle is primarily due to the complexities of problem-solving. Students deal with these struggles by employing mechanisms that could be classified into either problem-focused or emotion-focused coping strategies. The study was implemented through a design-research approach by using a model-building framework with four stages: 1) analysis; 2) development; 3) implementation/validation; and 4) evaluation. The models with the two variables were also linked to the student's sexual orientation and academic programs. Through descriptive statistical measures, such as frequency count and percentages, difficulties were enumerated through the administration of a problemsolving test. It should be noted, however, that a respondent may have at least one difficulty in the different phases of problem-solving. Two hundred and ninety-seven of the 425 college respondents were involved in the model-development stage. The majority of both males and females experienced the same difficulty/ies in all the phases, namely; the inability to distinguish the known from the unknown information (U1), the inability to transform a problem into a mathematical equation (D1), the inability to completely perform the working procedure systematically and accurately (C1), and the inability to start the evaluation of the correctness of the obtained solution (L2). The majority of the respondents of both the STEM-related and non-STEM-related academic programs experienced the same difficulties, namely: D1, C1 and L2 in the DP, CP and the LB problem-solving phases, respectively. In the UP phase,
\end{abstract}

* Correspondence concerning this article should be addressed to Dinah C. Vidad, Mariano Marcos State University, Batac City, Ilocos Norte, Philippines. Email: dcvidad@mmsu.edu.ph 
however, the majority of the respondents in the STEM-related academic programs experienced $\mathrm{U} 2$, and $\mathrm{U} 1$ for the non-STEM-related academic programs. Moreover, 43 acts of coping were elicited from the respondents through a coping-strategy questionnaire, 32 of which were classified as problem-focused, whereas 11 were categorized as emotion-focused. Both sexes utilized the coping strategies: UP2, DP8 and CP7 in the phases of $\mathrm{UP}, \mathrm{DP}$ and CP respectively. In the LB phase, LB3 was utilized by the males and LB1 was utilized by the females. The majority of the respondents of the STEM-related academic programs preferred UP2, DP8, CP7 and LB1 coping strategies, while UP2, DP8, CP7 and LB3 opted for the non-STEM related academic program respondents. The identified relationships between and among the variables brought forth two models namely: Coping Strategy by Sex by Phase, and Coping Strategy by Academic Program by Phase. Purposive sampling factors, like the availability of the respondents and the matching of coping strategies, as presented in the models developed were taken into consideration in evaluating the effectivity of the models. From the sampled respondents in the validation group, where the frequency of their pre-identified difficulties had either decreased or were totally resolved. The study concludes that the models have the ability to address the difficulties of the students in their problem-solving encounters through their coping strategies. Therefore, this study recommends that teachers should provide students with problem-solving tasks that focus on the phases in which they struggle. Additionally, this study encourages teachers to allow their students to apply their most-preferred coping strategies, so that they could perform better in Mathematics problem-solving.

Keywords: Mathematics problem-solving; problem-solving difficulties; problem-solving coping strategies; model-building

\section{Introduction}

Studies on educational assessment show that students experience difficulties in Mathematics, particularly in problem-solving. This could be a difficulty in at least one of the four phases (Polya, 1945), namely: understanding the problem, devising a plan, carrying out the plan, and looking back. Moreover, other studies also examined the diverse ways in which students cope with such difficulties. These coping strategies are commonly classified under two general categories, which are problem-focused and emotion-focused (Folkman \& Lazarus, 1980; 1985). Nevertheless, studies that investigate how these variables are associated with learners' sexual orientations and/or academic programs are scarce.

A number of studies related to problem-solving difficulties abound in the online literature. In the scholarly work of Siniguian (2017), respondents demonstrated difficulties in carrying out the plan and looking-back phases. Sultan's (2014) study, on the other hand, revealed that students have difficulty in translating word problems into mathematical phrases, when given word problems in Algebra. In a similar vein, the study conducted by Dela Cruz and Lapinid (2014) also found that learners not only struggle in translating word problems, but also experience difficulty in Mathematics, due to carelessness, lack of comprehension, interchanging values, and unfamiliar words. Meanwhile, Ferguson (1980) 
believed that students have "reading" deficiencies, where symbols and abstractions are concerned. This deficiency can be classified under Polya's (1945) understanding of the problem phase.

According to Ferguson (1980), reading does not simply refer to the ability to pronounce the words, or attach names to the symbols, rather, it necessitates the ability to comprehend the material. Studies embarking on different academic programs correspondingly reveal the problem-solving difficulties of students. In a science class, Nikmah et al. (2019) found that students struggle in devising a plan, when they tried to get the maximum value through the concept of first derivatives of algebraic functions. Meanwhile, in a Statistics class, problems relating to permutation and combination were found with the students.

Sukoriyanto et al. (2016) showed that students make a mistake in understanding the problems that resulted to a mistake when planning the problem's solution. They too made a mistake in rechecking the given information in the problem. All of this information generally confirms that difficulties exist in problem-solving. Driven by interest and curiosity, this study specifically identified the difficulties that are particular to the males and those that relate to the females. Moreover, with the K-12 curriculum, the study compared the encountered problem-solving difficulties between the STEM-related and the non-STEM-related academic programs.

Many studies, which can be observed in publications and other researchdissemination platforms, have already looked at the various ways of coping with the struggles relating to Mathematics. Generally, these coping strategies come in two forms: problem-focused and emotion-focused. Problem-focused coping strategies are efforts to reduce stressful circumstances, while emotion-focused strategies are efforts to regulate the emotional consequences of stressful events (Folkman \& Lazarus, 1980; 1985).

Coping with strategy preferences of the individual depend on the area in which he or she experiences the difficulty. One study maintained that problem-focused strategies are most preferred by students in the Western societies (Ader \& Erktin, 2012; Lazarus, 1993). A study by Rioveros (2013) revealed otherwise. Tension reduction and emotional engagement, both of which are emotion-focused coping strategies, were the coping strategies most preferred by the respondents, and seeking social support, which is a problem-focused coping strategy, was the least employed.

The information presented comprises the strategies generally utilized by students in managing their painful or difficult moments relating to Mathematics. The desire to unravel the strategies classified by gender and by academic program pushed the study to employ a survey questionnaire that elicited the students' most preferred coping strategies.

While many research projects deal with the difficulties and the coping mechanisms in Mathematical problem-solving, there is conversely a dearth of studies that show the relationships between difficulties and coping strategies via sex and via the academic program. Taking into account this gap in the literature, this article is directed towards developing models that are based on the difficulties 
and coping strategies of students in Mathematical problem-solving, and how these are related to the students' sex and academic programs. Ultimately, these models are expected to effectively respond to the struggles of students, when it comes to accomplishing problem-solving tasks in Mathematics.

\section{The Literature Review}

This section starts by discussing the different kinds and reasons for students' problem-solving difficulties, and how these could be connected to one's sexual orientation. The discussion then transitions to the varied ways students employ to cope with their difficulties. It is also explained how coping strategies can be influenced by one's sex and academic program. Finally, this section concludes with explaining how model-building could serve as an educational intervention to address the gaps and the issues identified.

\subsection{The Current Status of Mathematics Education}

The majority of people would argue that Mathematics is a subject in which students struggle to comprehend and solve mathematical word problems. In fact, several studies support this claim. The Grade 12 students of Lopez (2008) appeared to have an understanding of Mathematics that does not extend much beyond problem-solving with whole numbers. It is to be emphasised that senior high school graduates must have already acquired the knowledge on the different sets of numbers; and this knowledge is not only confined to whole numbers. This situation may have contributed to the downward trend of achievement levels and the survival rates of elementary and high school students, based on the National Achievement Tests (NAT) from 2005 to 2010, that is, from having a mean percentage score (MPS) of 49.26 to 47.40 in 2008-2009 and down to 46.30 in 20092010 (Ronda, 2011).

In support of this information, the study of Banilower et al. (2013) revealed that the performance of Philippine students in the international standardized examination in Mathematics and Science is generally classified as being low.

\subsection{Problem-Solving Difficulties}

Difficulties in solving Mathematical problems are mainly due to the lack of mathematical skills. Polya (1945) characterized the difficulties in each of the four phases as follows. There is a difficulty in understanding the problem, if one cannot identify the type of problem; while the known and the unknown information, cannot recall facts or concepts, cannot define the terminologies and notations used, and cannot rephrase the problem in one's own words. There is a difficulty in devising a plan, if one cannot draw a picture, tables or charts out of the information; if one is unable to transform problems into mathematical sentences; and if one cannot look for patterns.

If one cannot work with the systematic-working procedure (computational process) in solving the problem in ensuring its accuracy, then one is struggling with carrying out the plan, and if one is unable to evaluate the correctness of the obtained solution that would ensure consistency with the facts of the problem, then he or she has a problem with the looking-back phase. 
Several studies confirm the struggles of students in the different phases. Ferguson's (1980) study revealed reading, which is a component of understanding the problem, was the single greatest problem in learning Pre-Calculus Mathematics in college. He also added that reading should not simply mean the ability to pronounce the words or attach names to the symbols, but also the ability to comprehend the material. This belief was further strengthened by a study conducted by Pearce and his colleagues (2013), where it was revealed that the greatest percentage $(45 \%)$ of his respondents had problems with reading and understanding the problem. Only one cited the problem on computation, while the remaining percentages accounted for the rest of the phase difficulties.

On the other hand, Dela Cruz and Lapinid (2014) revealed that translating worded problems into mathematical symbols was the single greatest difficulty for students. This is due to carelessness, lack of comprehension, interchanging values, and to the unfamiliar words used in the problem. In addition, it was found in a study involving the subject of Physics that the students were unable to remember the relavent equations (Reddy \& Panacheroensawad, 2017). In solving those problems that involved derivatives, Nikmah et al. (2019) also discovered that students struggle to devise a planning phase. This was evident when the students tried to seek the maximum value when applying the concept of the first derivative of an algebraic function. The reasons behind this difficulty include the lack or the inadequacy of exercises during classes, lack of understanding the fundamental basics, poor mathematical skills in the necessary understanding of the problem, lack of motivation and inexperienced teachers, poor comprehension skills in definitions, the laws and the basic principles of physics, in addition to the lack of materials in problem-solving.

These difficulties, as discovered by Sukoriyanto et al. (2016), were also evident in a Statistics class, when they were attempting to solve the problems relating to permutation and combination. The students committed an error in understanding the problems that resulted in an error in planning the problem's solution and likewise, this led to an error in rechecking the given information in the problem. This proves that poor mathematical skills and that the lack of understanding the problem comprise the major obstacles in the domain of problem-solving skills.

In other Mathematics-related courses, like Chemistry, some students could correctly solve problems without being able to represent the reactions with an illustration (Nurrenberg \& Pickering, 1987; Sawrey, 1990, as cited in Finney, n.d.). This ability of the student falls under the "carrying out the plan" (computational) strategy. They were good at this stage; but they had difficulties involving the "devising a plan" phase. Meanwhile, carrying out the plan and looking back were found to be the major phase difficulties in solving mathematical problems, based on a study conducted by Siniguian (2017).

The inability to translate problems into mathematical equations and the inability to apply mathematical concepts and principles correctly, were the reasons for these phase difficulties. These difficulties were also evident in describing the problem-solving skill of senior high school students of a certain high school in a 
foreign country. By administering PISA test items, the results showed a very low category for both devising a plan (DP) and looking back (LB) phases, as well as a medium category for carrying out the plan (CP) phase (Arfiana \& Wijaya, 2018).

Difficulties in accomplishing problem-solving tasks may also be affected by the sexual orientation of an individual. Between the two sexes, Ganley (2018) observed that there are more female respondents who encountered difficulties in each phase of problem-solving than did the male respondents. This could be attributed to the female's low levels of confidence in their Mathematical skills than with males.

\subsection{Students' Coping Strategies}

The term "coping" refers to the thoughts and actions, to which one resorts, when dealing with a stressful situation (Cliche, 2017). Some coping strategies, however, are not as helpful as others. While positive coping strategies give opportunities to actively work towards solving the problems, negative coping strategies make anyone wear down over time; and they often aggravate the situation. Ideally, positive coping strategies include listening to music, going out with a friend, discussing situations with a friend, making an action plan to solve a problem, or seeking counselling to deal with stress; whereas negative coping strategies involve criticizing oneself, yelling at friends, taking a recreational drug, becoming aggressive, or simply avoiding friends and family. Anybody can become stressed for various reasons in different fields and situations; consequently, we need to choose the appropriate coping strategy.

Folkman and Lazarus $(1985 ; 1980)$ developed and devised a measure called the Ways of Coping, which consists of a series of predicates, each portraying a coping action that people sometimes engage in when under stress. They categorized coping strategies into two categories - problem-focused and emotion-focused.

a) Problem-focused coping is generally viewed as an adaptive mode of coping that involves actively planning or engaging in a specific behavior, in order to overcome the problem that is causing distress (Folkman \& Lazarus, 1985). The examples of problem-focused coping include planned problem-solving, confrontive/active coping and seeking social/instrumental support, such as friends, families, supervisors and mentors.

b) Emotion-focused coping involves attempts to regulate the emotions evoked by the occurrence of a stressful situation; and it can be considered active or avoidant (Holahan \& Moos, 1987; Ryan, 2013). Also, emotion-focused coping may involve the use of behavioral and/or cognitive strategies, such as receiving emotional support from friends and family and positive reframing (Ogden, 2004; Ryan, 2013).

How do the students cope with their stressors? There are a variety of these coping strategies, some are better and more effective to students' learning than others. The following literature illustrates the strategies used by the respondents when confronting their stresses. The respondents of Kahraman and Sungur (n. d), as cited in Rioveros (2013) stated that they cope with their difficulty in three stages. The first involved students defining the event as an obstacle to their goals. Then,

http://ijlter.org/index.php/ijlter 
they think of the possible strategies to handle the negative event, and choose one among them. The last stage involves students applying the chosen solution.

Moreover, an examination of the experiences of stress and the coping strategies of high school students in a university (Baluyou, 1999; Rioveros, 2013) revealed that self-control, distancing, and planned problem-solving were useful and effective coping strategies. Problem-focused coping tends to predominate, when people feel that something constructive ought to be done, whereas emotion-focused coping tends to predominate, when people feel that the stressor is something that must simply be endured (Carver, et al., 1999; Folkman \& Lazarus, 1980; Ghana, 2011). Due to their action-orientation, problem-focused coping strategies are more highly valued in Western societies (Ader \& Erktin, 2012; Lazarus, 1993).

\subsubsection{Gender and Coping}

Based on sex-typed predispositions, men and women adopt different coping strategies, a theory that has been frequently explored. Men would be expected to utilize problem-focused coping more than women. Men used significantly more direct actions (Rapson, 1990), and less frequently used active-behavioural avoidance and emotion-focused coping (Billings \& Moos, 1984, as cited in Rapson, 1990; Eschenbeck, et al., 2002). Women, on the contrary, are expected to use more emotion-focused coping than do men (Brougham et al., 2009; Hammermeister \& Burton, 2004; Kaiseler et al., 2012). They tend to use more distraction, catharsis, seeking social support, relaxation and other types of coping (Rapson, 1990; Stone \& Neale, 1984), in addition to information-seeking and emotional discharging (Billings \& Moos, 1984, as cited in Rapson, 1990).

Tamres and colleagues (2002) revealed that women are more likely to use strategies that involve verbal expressions to others or the self - than to seek emotional support, ruminate about problems, and use positive self-talk.

\subsubsection{Academic Programs and Coping}

A few studies reveal that students of different courses encounter varied mathematical difficulties, hence, with varied coping strategies. In a study involving BEED (Bachelor of Elementary Education) and BSEd (Bachelor of Secondary Education) students, it was disclosed that listening attentively to the teacher was the most significant coping mechanism, if one had no focus on Math tasks and one was easily distracted by external factors (Bagasol et al., 2015). The use of diagrams and pictures out of the probles and engaging in leisure activities were found to be the least-significant coping mechanisms for the students enrolled in BEED and BSEd courses, respectively.

In the field of health and medicine, nursing students experienced different levels of stress that include the caring for patients, assignments and workloads, and negative interactions with staff and faculty; thus, they utilized problem-solving strategies, such as developing objectives to resolve problems, adopting various strategies to address problems, and finding the meaning of stressful events (Labrague et al., 2016), which were all problem-focused coping strategies.

Finalyson (2014, as cited in Quan, 2015), maintained in his survey paper that relaxing, building self-confidence, practice, studying and doing one's homework 
and getting help from others were the most preferred problem-focused coping strategies. On the contrary, among general education students, active coping, which is another form of problem-focused coping strategy, was revealed as being the most frequently used strategy (Okoro, 2018).

\subsection{Model-Building}

Model-building provides a framework that guides the researcher in addressing the objectives of this study. Some empirical studies have already employed the model-building framework as their research design; and they have found it efficient and effective in attaining research aims. Houghton and his colleagues (2012), through the model that they developed, suggested that effective motion regulation and self-leadership, mediated through positive affect and self-efficacy have the potential to facilitate stress-coping among students. In another research context, challenged with technology-education students, Ernst (2009) focused on the development of problem-solving models that employ societal, cultural, and economic considerations. The results revealed no apparent effect on the initial component selection of problem-solving modelling, whether challenged with environmental or manufacturing issues. In the area of combinatorics, a model of student's combinatorial thinking, related to counting, was developed by Lockwood (2013). This model elaborated on the relationships between formulas/expressions, counting processes and sets of outcomes. Likewise, it served as an initial attempt for providing ideas and common language that researchers could utilize in evaluating their own students' combinatorial thinking and activities.

\section{The Research Methodology}

Figure 1 shows the model-building framework that was followed in conducting this study. It employed a design-research approach with four components analysis, development, implementation, and validation. The data were gathered by administering a problem-solving test and a coping-strategy questionnaire. The study is generally descriptive that employed quantitative and qualitative analysis.

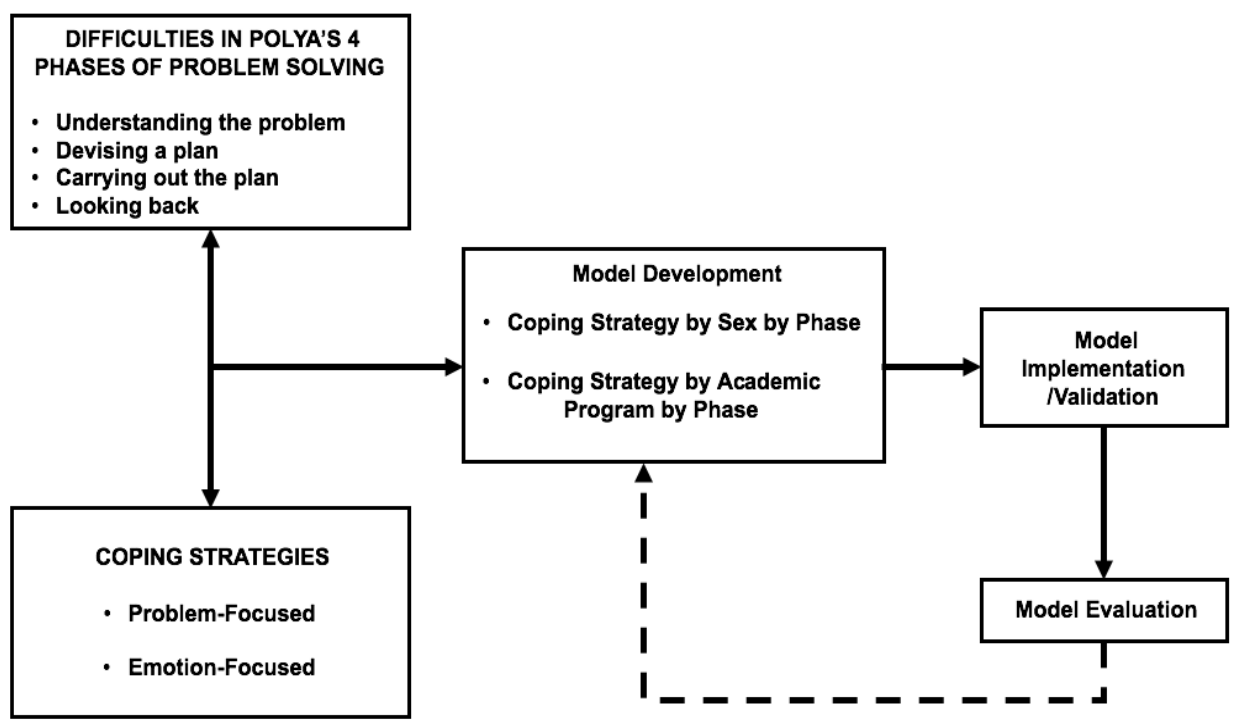

Figure 1: The Model-Building Framework of the Study 
The Analytical Stage. This stage dealt with the analysis of the Mathematics problem-solving difficulties of the students by administering a problem-solving test. Likewise, coping strategies were elicited from the respondents by requesting them to answer the Coping -trategy Questionnaire. Two difficulties in each of the problem-solving phases were revealed; and the students preferred the Problemfocused coping strategies for dealing with with their difficulties.

The Model-Developmenal Stage. Two models associating the Mathematical problem-solving difficulties and coping strategies of the students were generated and developed, namely: the coping strategies by sex by phase model, and the coping strategies by the academic program of the phase model. These models were linked with the students' sexual orientations and academic programs.

Model Implementation. This stage validated the models developed by engaging the students (validation group) through the administration of a similar problemsolving test. Purposive sampling was employed in validating the models. Factors, such as the availability of the respondents and the matching of coping strategies ,as presented in the models developed, were taken into consideration.

The Model-Evaluation Stage. This stage assessed and determined whether the problem-solving difficulties of the students were addressed, or not, through the coping strategies, as modelled. A decrease, or a total eradication of the preidentified difficulties, concluded the effectivity of the models developed, that is, they could address the difficulties of the students in their problem-solving encounters through their coping strategies. A total of 425 respondents participated in the study. The distribution of these respondents, based on their sex, and on the academic program is clearly presented in Table 1 . They were enrolled in Mathematics in the Modern World, offered in a certain Philippine university during the first semester of the school year 2018-2019. The respondents belonged to the same year level, within the 18-19 year-old age bracket; and they were considered to be the first graduates of the K-12 curriculum.

Table 1: Distribution of respondents by sex and academic program

\begin{tabular}{|l|c|c|c|c|}
\hline \multicolumn{1}{|c|}{ Academic Programs } & $\begin{array}{c}\text { Number of } \\
\text { Classes }\end{array}$ & $\begin{array}{c}\text { Number of } \\
\text { Males }\end{array}$ & $\begin{array}{c}\text { Number of } \\
\text { Females }\end{array}$ & Total \\
\hline STEM-related academic programs & 28 & 43 & $\mathbf{7 1}$ \\
\hline $\begin{array}{l}\text { BS-Agricultural and } \\
\text { Biosystems Engineering }\end{array}$ & 2 & 10 & 12 & $\mathbf{2 2}$ \\
\hline BS-Chemical Engineering & 1 & 67 & 46 & $\mathbf{1 1 3}$ \\
\hline BS-Civil Engineering & 3 & 5 & 21 & $\mathbf{2 6}$ \\
\hline BS-Mathematics & 1 & 9 & 8 & $\mathbf{1 7}$ \\
\hline BS-Meteorology & 1 & 15 & 62 & 77 \\
\hline BS-Nursing & 2 & $\mathbf{1 3 4}$ & $\mathbf{1 9 2}$ & $\mathbf{3 2 6}$ \\
\hline Subtotals & &
\end{tabular}

http://ijlter.org/index.php/ijlter 


\begin{tabular}{|l|c|c|c|c|}
\hline Non-STEM-Related academic programs \\
\hline BA-Communication & 1 & 8 & 24 & $\mathbf{3 2}$ \\
\hline BS-Economics & 1 & 11 & 25 & $\mathbf{3 6}$ \\
\hline BS-Sociology & 1 & 8 & 23 & 31 \\
\hline Subtotals & & $\mathbf{2 7}$ & $\mathbf{7 2}$ & $\mathbf{9 9}$ \\
\hline OVERALL TOTAL & $\mathbf{1 6 1}$ & $\mathbf{2 6 4}$ & $\mathbf{4 2 5}$ \\
\hline
\end{tabular}

The study needed two independent groups - the model -evelopment group and the model-validation group. The grouping scheme applied the 70-30 scheme of partitioning the students. This scheme, according to Pete (2017), is arbitrary. However, the more respondents that are included in the development stage (70\%), the better the developed model. Of the 425 respondents, 297 respondents represented the $70 \%$; and they were included in the model development with the distribution of respondents by sex and academic program, as found in Table 2 . This sum was identified through random sampling, specifically done through a table of random numbers generated by stattrek.com. The selected samples, however, had their final say by their participation in this study.

Table 2: Distribution of respondents by sex and academic program in the modeldevelopmental stage

\begin{tabular}{|l|c|c|c|}
\hline \multicolumn{1}{|c|}{ Course } & Male & Female & Total \\
\hline STEM-Related academic programs & & & \\
\hline BS-Agricultural and Biosystems Engineering & 22 & 28 & $\mathbf{5 0}$ \\
\hline BS-Chemical Engineering & 8 & 7 & $\mathbf{1 5}$ \\
\hline BS-Civil Engineering & 48 & 31 & $\mathbf{7 9}$ \\
\hline BS-Mathematics & 3 & 15 & $\mathbf{1 8}$ \\
\hline BS-Meteorology & 8 & 4 & $\mathbf{1 2}$ \\
\hline BS-Nursing & 11 & 43 & $\mathbf{5 4}$ \\
\hline Sub-totals & $\mathbf{1 0 0}$ & $\mathbf{1 2 8}$ & $\mathbf{2 2 8}$ \\
\hline Non-STEM-related academic programs & 5 & 17 & $\mathbf{2 2}$ \\
\hline BA-Communication & 9 & 16 & $\mathbf{2 5}$ \\
\hline BS-Economics & 4 & 18 & $\mathbf{2 2}$ \\
\hline BS-Sociology & $\mathbf{1 8}$ & $\mathbf{5 1}$ & $\mathbf{6 9}$ \\
\hline Subtotals & $\mathbf{1 1 8}$ & $\mathbf{1 7 9}$ & $\mathbf{2 9 7}$ \\
\hline TOTALS
\end{tabular}

Meanwhile, the developed models were validated by the remaining 128 respondents that represented the $30 \%$ of the total respondents, as can be seen in the distribution in Table 3. Their participation was primarily aimed at testing whether the developed models are appropriate, and could eventually address the problem-solving difficulties of the students in the case samples. 
Table 3: Distribution of respondents by sex and academic program in the model validation stage

\begin{tabular}{|l|c|c|c|}
\hline \multicolumn{1}{|c|}{ Course } & Male & Female & Total \\
\hline STEM-Related academic programs & \multicolumn{2}{c|}{} \\
\hline BS-Agricultural and Biosystems Engineering & 8 & 13 & $\mathbf{2 1}$ \\
\hline BS-Chemical Engineering & 3 & 4 & $\mathbf{7}$ \\
\hline BS-Civil Engineering & 20 & 14 & $\mathbf{3 4}$ \\
\hline BS-Mathematics & 2 & 6 & $\mathbf{8}$ \\
\hline BS-Meteorology & 3 & 2 & $\mathbf{5}$ \\
\hline BS-Nursing & 4 & 19 & $\mathbf{2 3}$ \\
\hline Subtotals & $\mathbf{4 0}$ & $\mathbf{5 8}$ & $\mathbf{9 8}$ \\
\hline Non-STEM-related academic programs & \multicolumn{2}{c|}{} \\
\hline BA-Communication & 3 & 7 & $\mathbf{1 0}$ \\
\hline BS-Economics & 3 & 8 & $\mathbf{1 1}$ \\
\hline BS-Sociology & 2 & 7 & $\mathbf{9}$ \\
\hline Subtotals & $\mathbf{8}$ & $\mathbf{2 2}$ & $\mathbf{3 0}$ \\
\hline TOTALS & $\mathbf{4 8}$ & $\mathbf{8 0}$ & $\mathbf{1 2 8}$ \\
\hline
\end{tabular}

\subsection{The Research Instruments}

This study utilized two research instruments, in order to collect the data from the respondents. The first one was a problem-solving test, which aimed to determine the problem-solving difficulties of students in Mathematics. The second instrument was the coping-strategy questionnaire, which is appended to the last part of the problem-solving test. This instrument was used to identify the coping strategies deployed by the students, when attempting to deal with their difficulties.

\subsubsection{The Problem-Solving Test}

This test facilitated the identification of the problem-solving difficulties of the students. The test items were routine problems, which were applications in Algebra, such as problems of age, geometry/dimensions, work, mixture, investment/interest, motion, number relations and of money. Students' solutions were assessed by the researchers, which were then counterchecked by two of their validators. It was pilot-tested and had a Cronbach's alpha reliability of 0.79 , which was acceptable.

\subsubsection{The Coping-Strategy Questionnaire}

This questionnaire facilitated the identification of the common coping strategies of the students in solving mathematical problems. It was appended to the last part of the problem-solving test. The students were asked to share their past experiences, particularly in problem-solving situations. They were requested to share how they had managed their difficulties through their coping strategies.

\section{The Research Results}

This section discusses the research results, starting with the identification of the students' problem-solving difficulties. It then proceeds with the elaboration on students' preferred coping strategies. Lastly, models were developed showing the problem-solving difficulties, by sex, by phase and the students' problem-solving difficulties by academic program by phase. In this section of the paper, it should 
be noted that acronyms were used to represent the four problem-solving phases understanding the problem (UP), devising a plan (DP), carrying out the plan (CP), and looking back (LB).

\subsection{Problem-Solving Difficulties}

Two common difficulties in each of the four phases were revealed. The difficulties were coded with prefixes indicative of the problem-solving phase. These codes were introduced by the researchers themselves. It can be seen in Table 4, that the students encountered difficulties in the different phases of problem-solving, as supported by studies from Siniguian (2017), as well as those of other scholars.

Table 4: Problem-solving difficulties in the different phases

\begin{tabular}{|c|c|c|}
\hline $\begin{array}{l}\text { Problem-Solving } \\
\text { Phases }\end{array}$ & Identified Difficulties & Code \\
\hline \multirow{2}{*}{$\begin{array}{l}\text { Understanding } \\
\text { the Problem (UP) }\end{array}$} & $\begin{array}{l}\text { 1. Inability to distinguish the known from the } \\
\text { unknown information }\end{array}$ & U1 \\
\hline & $\begin{array}{l}\text { 2. Inability to identify the type of problem and } \\
\text { recall basic facts }\end{array}$ & $\mathrm{U} 2$ \\
\hline \multirow[b]{2}{*}{$\begin{array}{l}\text { Devising a Plan } \\
\text { (DP) }\end{array}$} & $\begin{array}{l}\text { 1. Inability to transform a problem into a } \\
\text { mathematical equation. }\end{array}$ & D1 \\
\hline & $\begin{array}{l}\text { 2. Inability to draw tables/charts out of the } \\
\text { information and organize information and } \\
\text { connect to a concept. }\end{array}$ & D2 \\
\hline \multirow{2}{*}{$\begin{array}{l}\text { Carrying Out the } \\
\text { Plan (CP) }\end{array}$} & $\begin{array}{l}\text { 1. Inability to completely perform the working } \\
\text { procedure systematically and accurately. }\end{array}$ & $\mathrm{C} 1$ \\
\hline & 2. Inability to start with the computational process. & $\mathrm{C} 2$ \\
\hline \multirow{2}{*}{$\begin{array}{l}\text { Looking Back } \\
\text { (LB) }\end{array}$} & 1. Inability to complete the checking procedure. & L1 \\
\hline & $\begin{array}{l}\text { 2. Inability to start the evaluation of the } \\
\text { correctness of the obtained solution. }\end{array}$ & L2 \\
\hline
\end{tabular}

The following are a few examples of the students' solutions, illustrating some of their difficulties in each of the phases.

\subsubsection{Understanding the Problem Phase (UP)}

Figure 2 shows the student's inability to distinguish the known from the unknown information. It can be clearly observed in the figure that the student merely lifted the words/phrases, as stated in the problem.

\section{Doony is twice as old as Jean. Throe yoars ago, the sum of their ages is 39. How ofd are they?

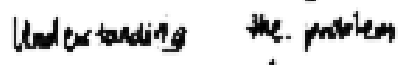

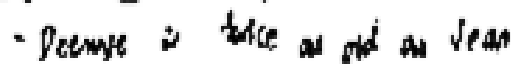

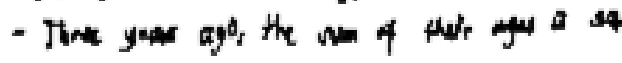

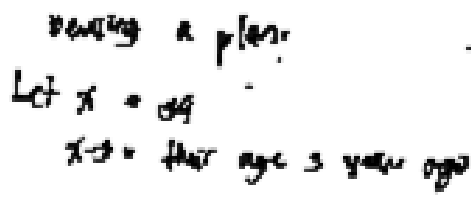

Figure 2. Solution of BS-ABE 
Figure 3 presents the student's immediate manipulation of his or her working equation without trying to distinguish the given/known and the unknown information of the problem. He or she was not able to identify the type of problem and to recall the basic concepts, thus, he/she left the space provided blank.

\section{Ellah has exacty P200 in P5 coins and P10 bills. He has twice as many P10 as}

P5. How many of each does he have? (Petilos, 2002)

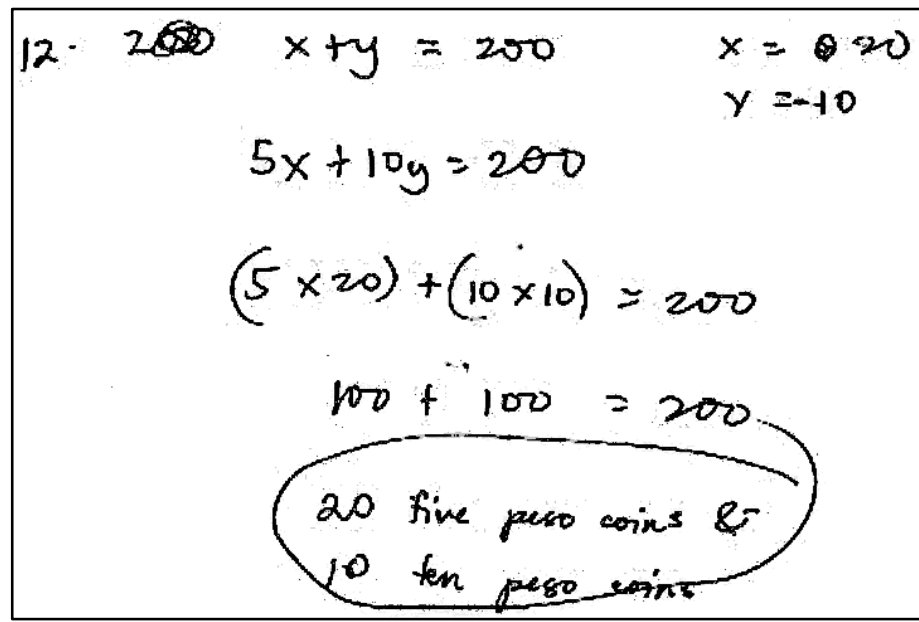

Figure 3: Solution of BA-COMM-1

Figure 4 shows the student's inability to distinguish the unknown information in the problem; and he/she just lifted the exact words used in the problem.

2. In consecutive tums of a Monopoly game, Stacy first paid P8,000.00 for a hotel. She then lost half her money when she landed on Boardwalk. Next, she collected $P 2,000.00$ for passing $G O$. She then lost half her remaining money when she landed on Illinois Avenue. Stacy now has P25,000.00. How much did she have just before sho purchased the hotel? (Aufmann, 2013)

known $=P 8,000$ first paid

- $\frac{1}{2}$ of morey wher ghe larded

is beardank

- she collected 2000 for passing Go

- lost it $\frac{1}{2}$ of her revainig marey

- 25000 final merey

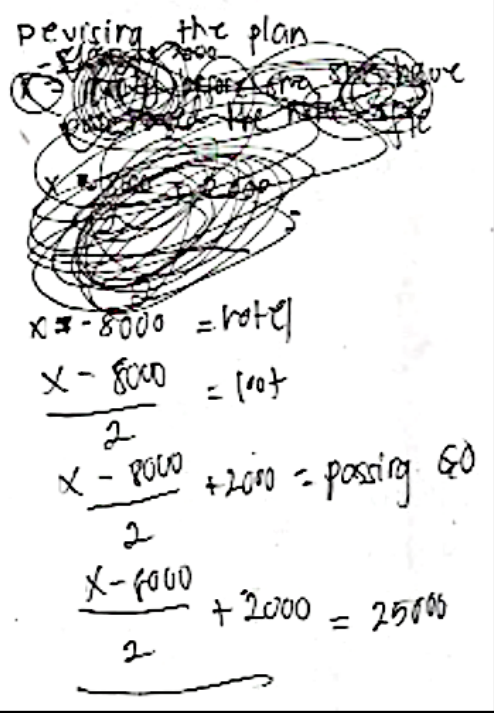

Figure 4: Solution of BSCE-B1

http://ijlter.org/index.php/ijlter 
Looking at the solution of Figure 5, the respondent completely left the space provided for understanding the problem phase. The student did not write anything about the problem's given and unknown information; because s/he was not familiar with the type of problem and could not recall basic facts.

19. Seven times a 2-digit number is equal to 4 times the number obtained by reversing the digits. The difference between the digits is 1 . Find the number.

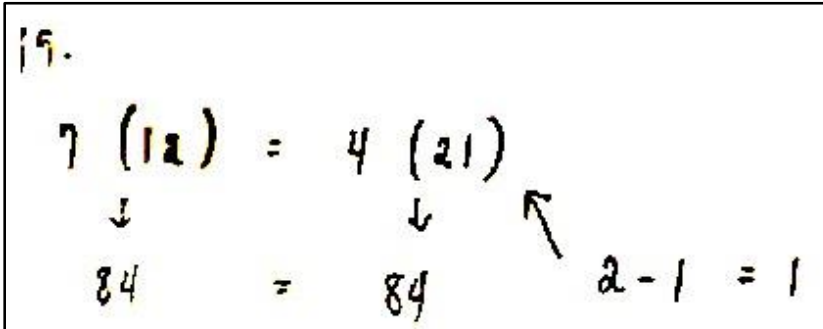

Figure 5: Solution of BSN-A2

\subsubsection{Devising a Planned Phase (DP)}

One can easily check that the student was unable to transform the problem into a mathematical equation in Figure 6.

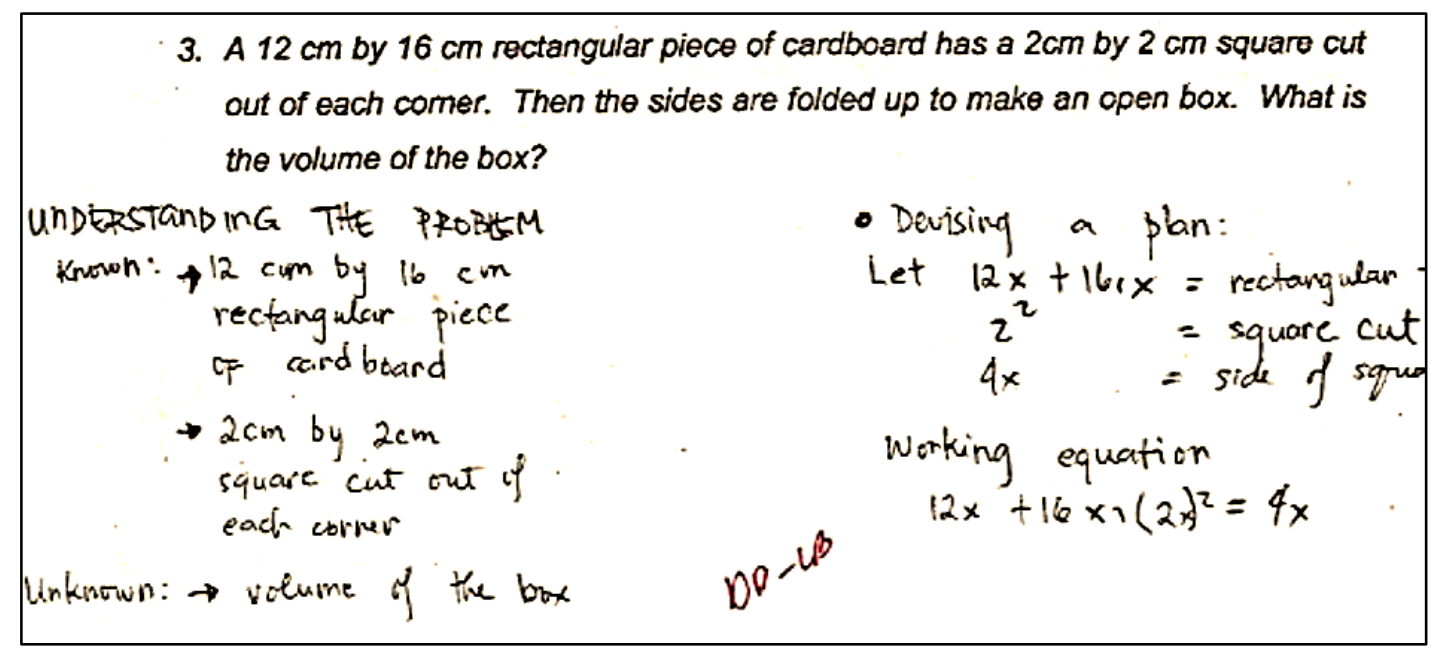

Figure 6: Solution of BS-Econ A16 
Figure 7 shows how the student worked well for the given situation, but was not able to formulate the mathematical equation that applied to the distance/motion problem. A diagram could have helped the student to analyze the situation.

7. Two cars leave a town and travel in opposite directions. Ono car travels at the rate of $45 \mathrm{kph}$, and the other at $55 \mathrm{kph}$. In how many hours will the two cars be 350 kilometers apart?

(1) Type. Nuander Pelations Miknoware hour the two car w

Kowir: $\operatorname{cor} A=45 \mathrm{kph}$
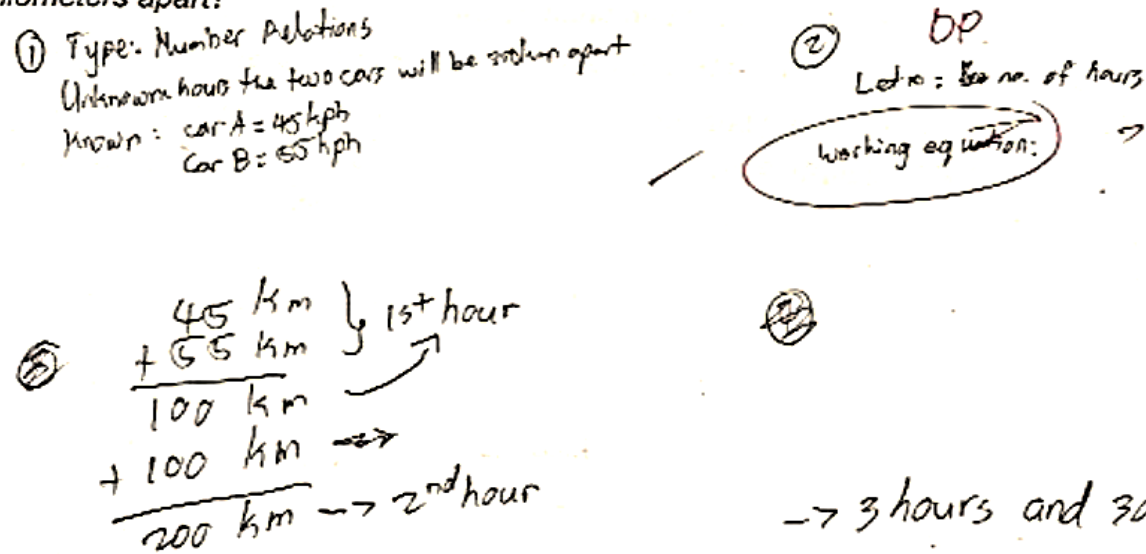

$\frac{100}{300 \mathrm{Km}-7} 3^{2 d}$ hour

$$
+\frac{60}{3,50-7} 3^{\text {rd hour }+30 \text { minutes }}
$$
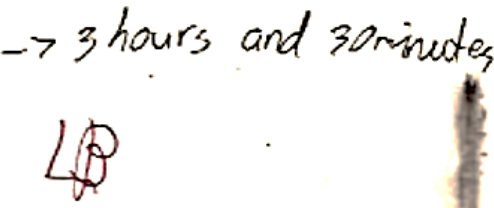

Figure 7: Solution of BS-Meteo I

Figure 8 shows the solution of the student, who incompletely formed the mathematical equation for the stated problem. Incomplete in a way that $\mathrm{s} / \mathrm{he}$ missed an expression to make the mathematical equation feasible.

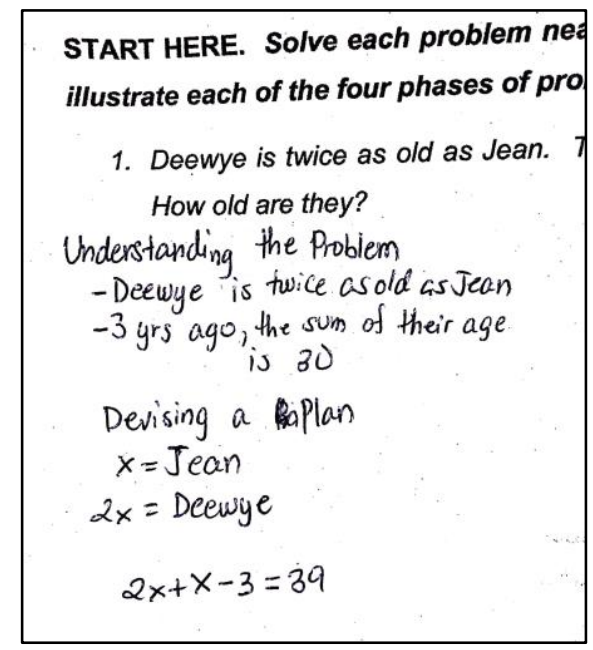

Figure 8: BA-Socio I 
Figure 9 shows that $\mathrm{s} /$ he was able to distinguish the unknown from the known information, however, $\mathrm{s} /$ he was unable to formulate the working equation.

9. Jenina owns a pet shop that specializes in tropical fishes. In April, Jenina doubled the number of fish she had on hand and then sold 30 of them. In May, she tripled the number of fish she had on hand, and then sold 54 of them, In June, she quadrupled the number of fish she had, and then sold 72 of them. Sho now had 48 fish left. How many fish did she start with? (Petilos, 2002)

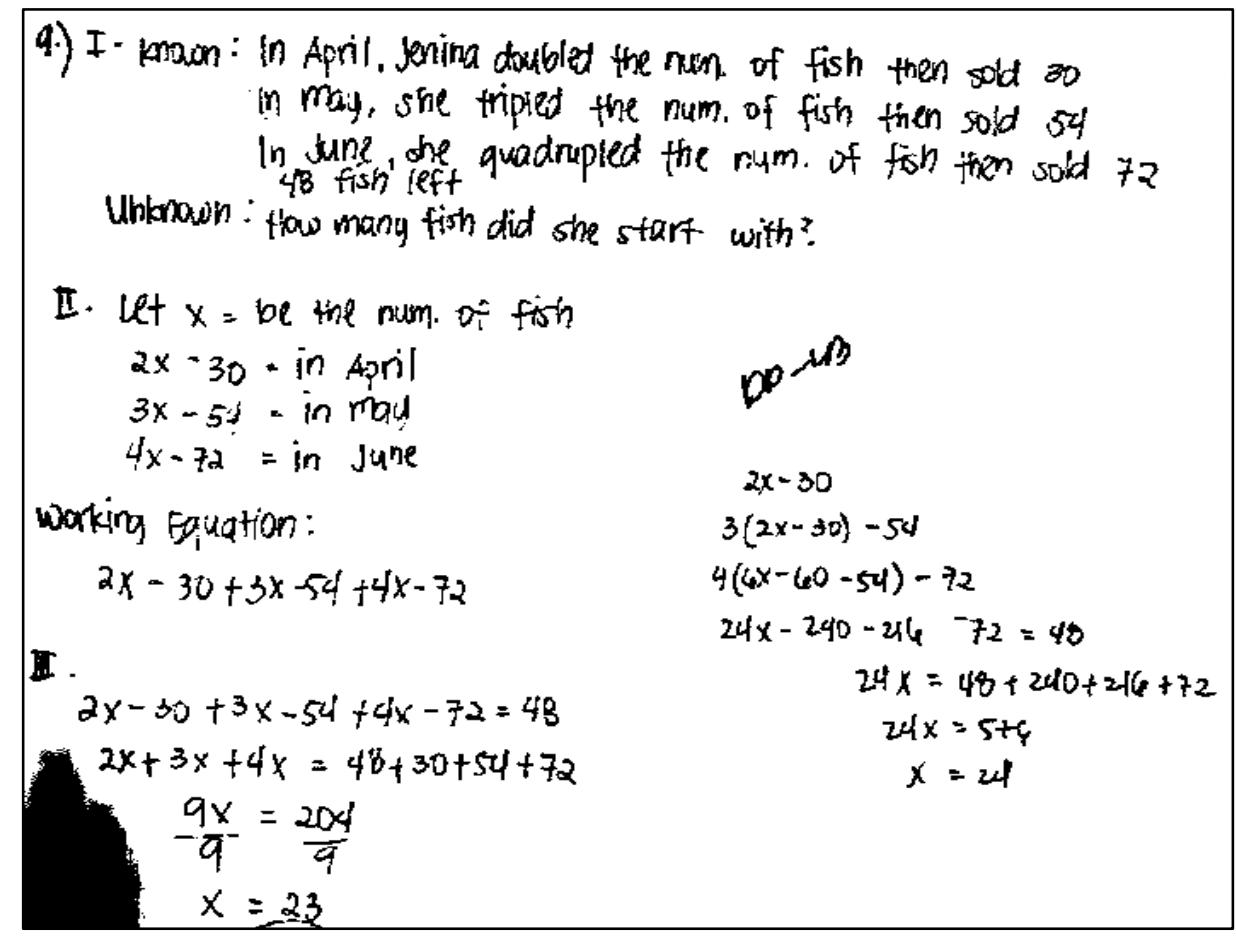

Figure 9: Solution of BS-CHEM E14

\subsubsection{Carrying out the Planned (CP) Phase}

In Figure 10, it can be observed that the mathematical equation formed is correct, but the student was not able to completely perform the working procedure accurately. 


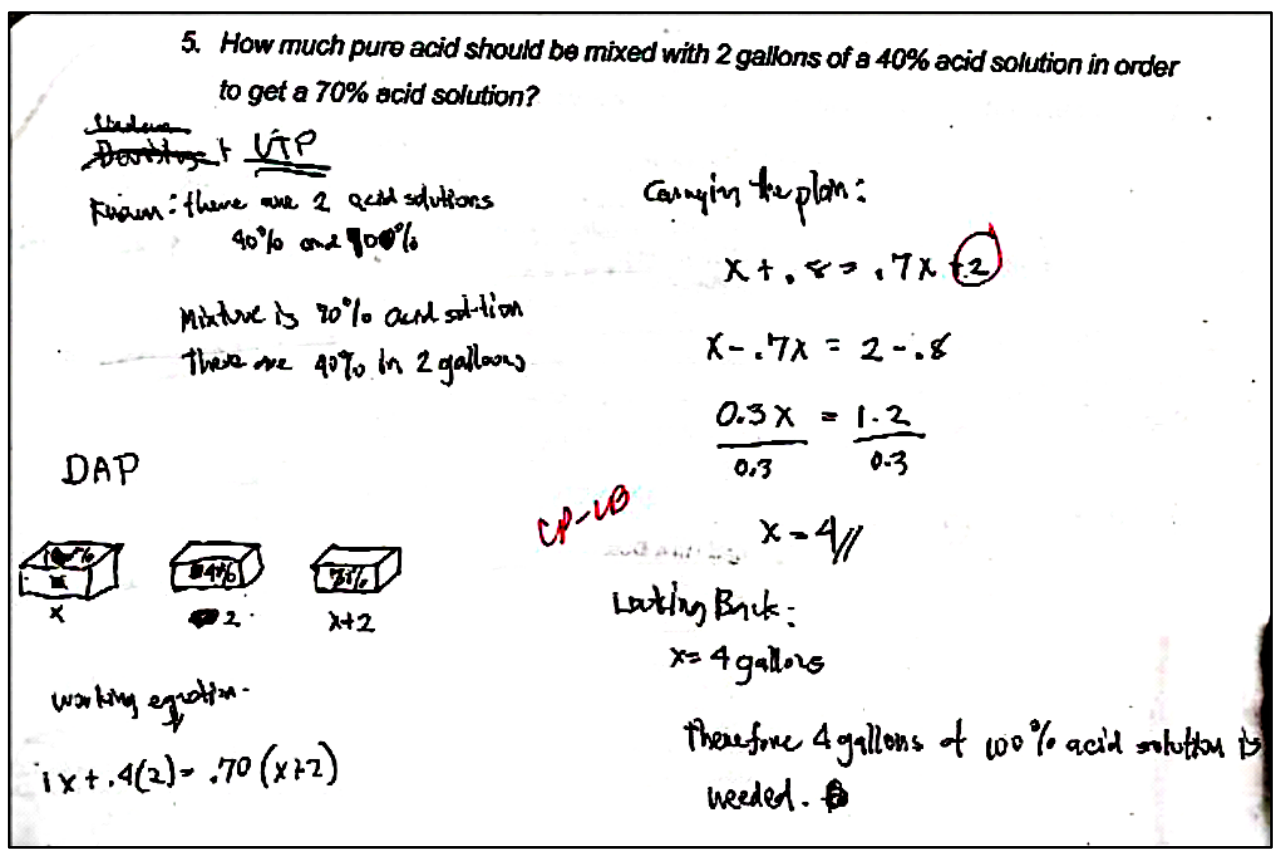

Figure 10: Solution of BSCE-A2

It can be observed that the student (Figure 11) was unable to start with the computational process because $\mathrm{s} / \mathrm{he}$ was not able to form the mathematical equation.

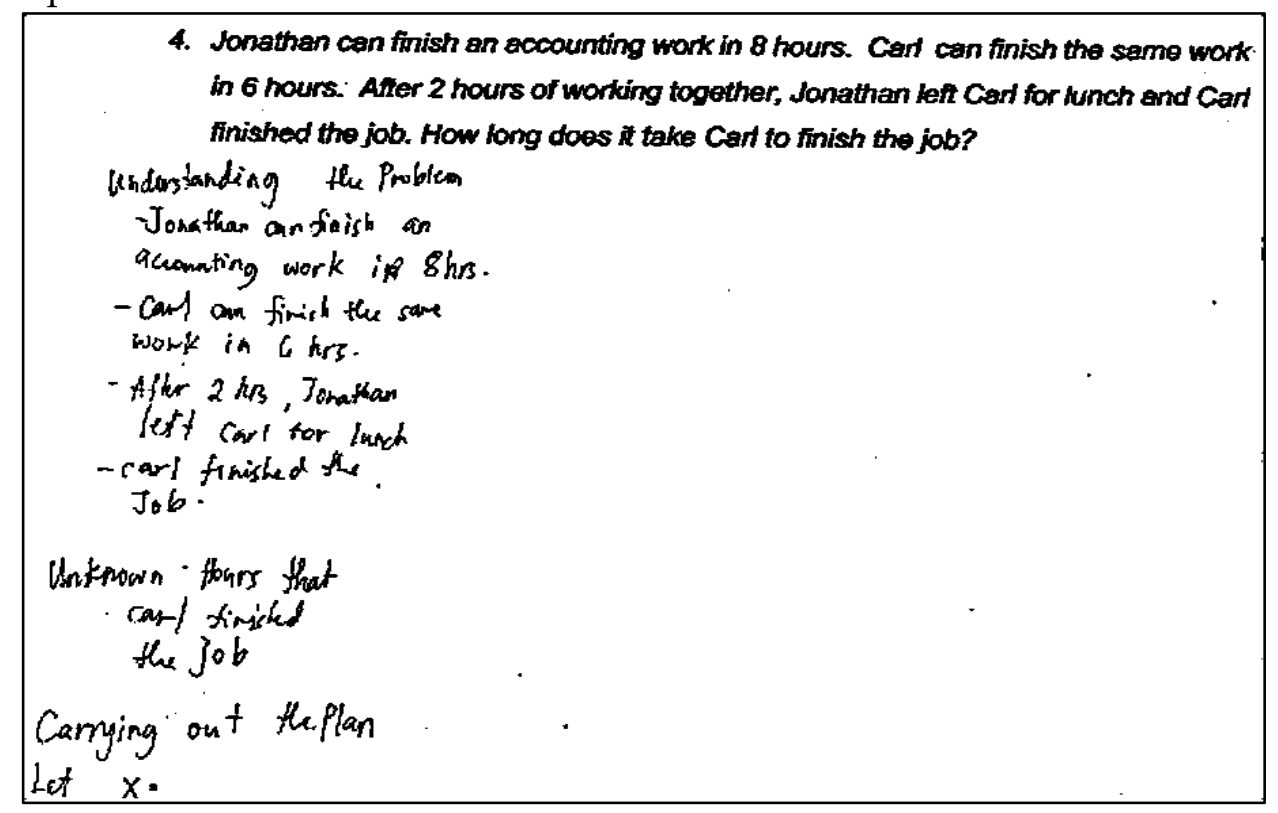

Figure 11: Solution of BS-ABE-B23

The difficulty of performing the computational process coincides with the findings of the study of Siniguian (2017) and Dela Cruz and Lapinid (2014), in which they investigated the difficulties experienced by the third-year college students in solving Mathematical problems. The study revealed that the difficulties are in the inability to translate into mathematical formulae (DP) that which consequently affected the student's computational process $(\mathrm{CP})$, and the inability to use correct mathematics (CP). 


\subsubsection{The Looking-Back Phase (LB)}

Figure 12 presents the procedure that went well; but the student was not able to complete the checking procedure.

8. The first of three numbers exceeds twice the second number by 4 , while the third number is twice the first. If the sum of the three number is 54 , find the numbers.

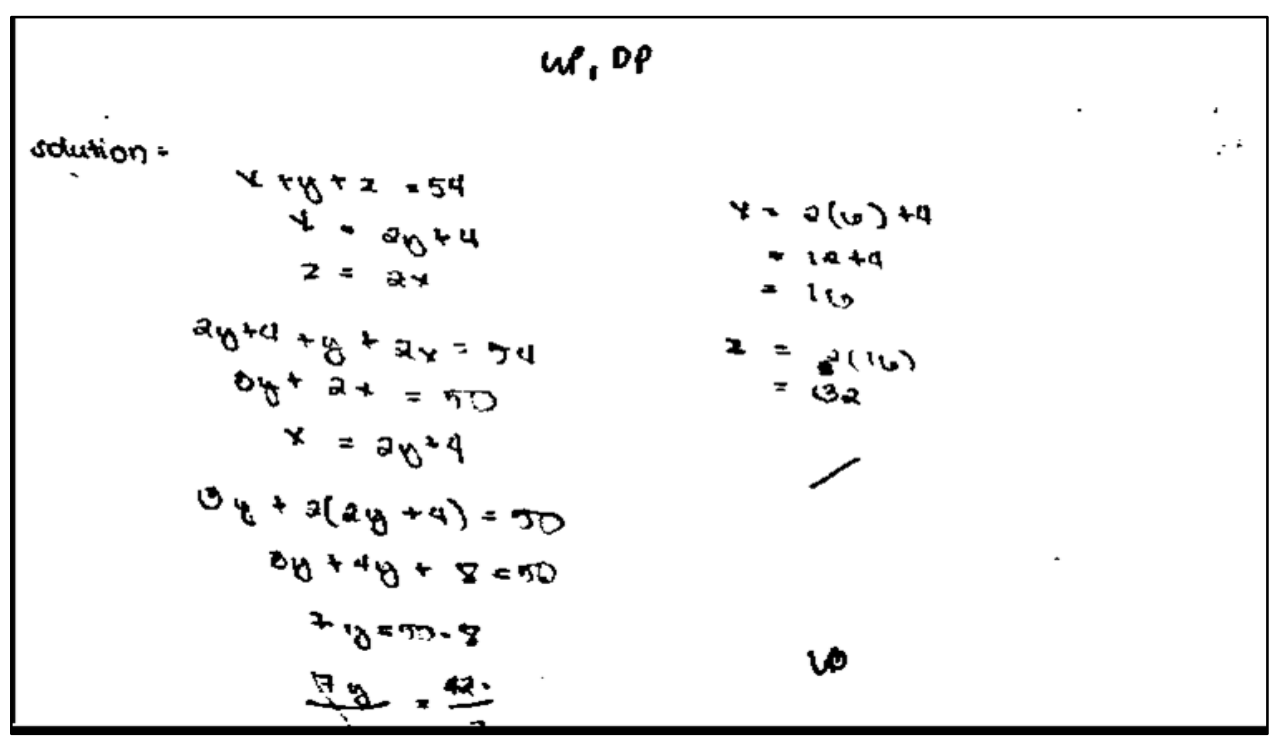

Figure 12: Solution of BSN-A1

In Figure 13, the student succeeded in performing the first three steps of Polya's (1945) four phases, although s/he was not able to start the evaluation of his or her obtained solution.

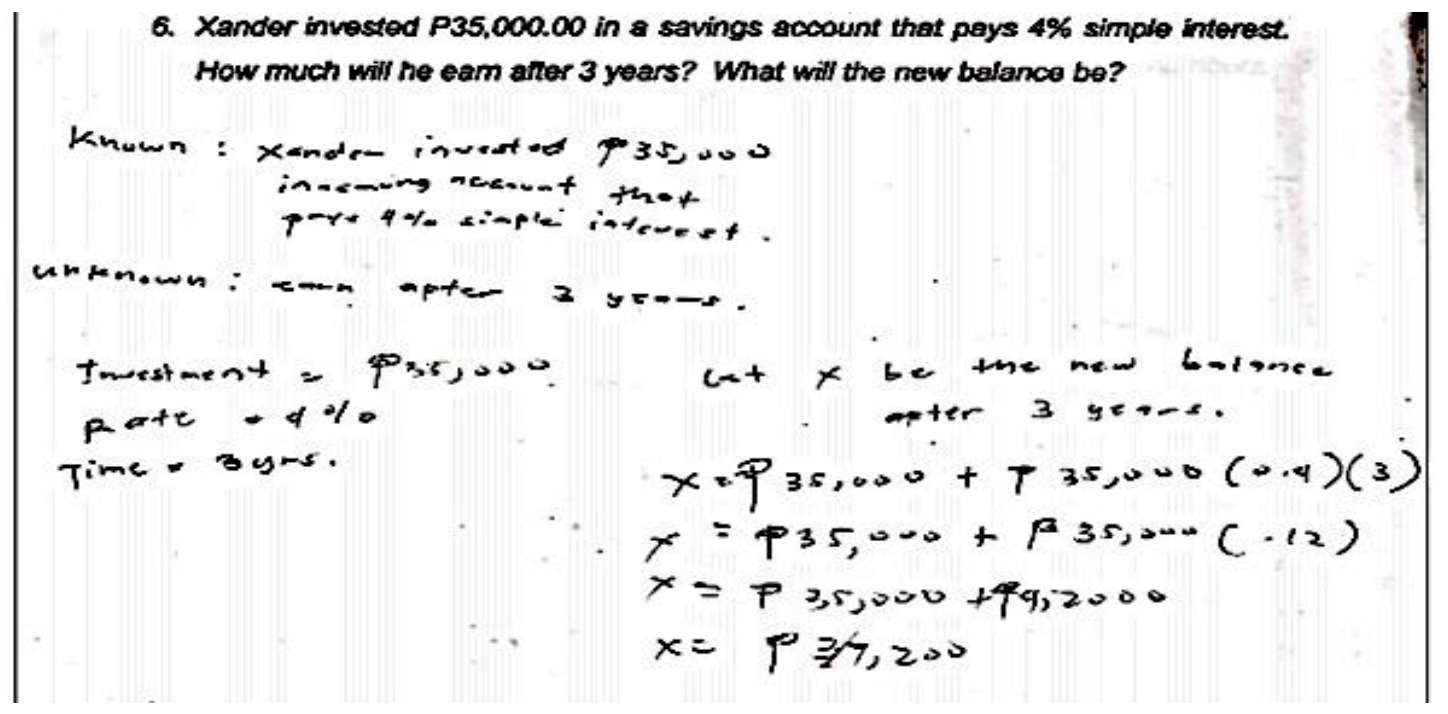

Figure 13: Solution of BS-Econ-15

In Figure 14, the student was able to recheck/re-evaluate the derived value; but it was not consistent with the the facts of the problem. 
6. Xander invested $P 35,000.00$ in a savings account that pays $4 \%$ simple interest. How much will he eam after 3 years? What will the new balance be?

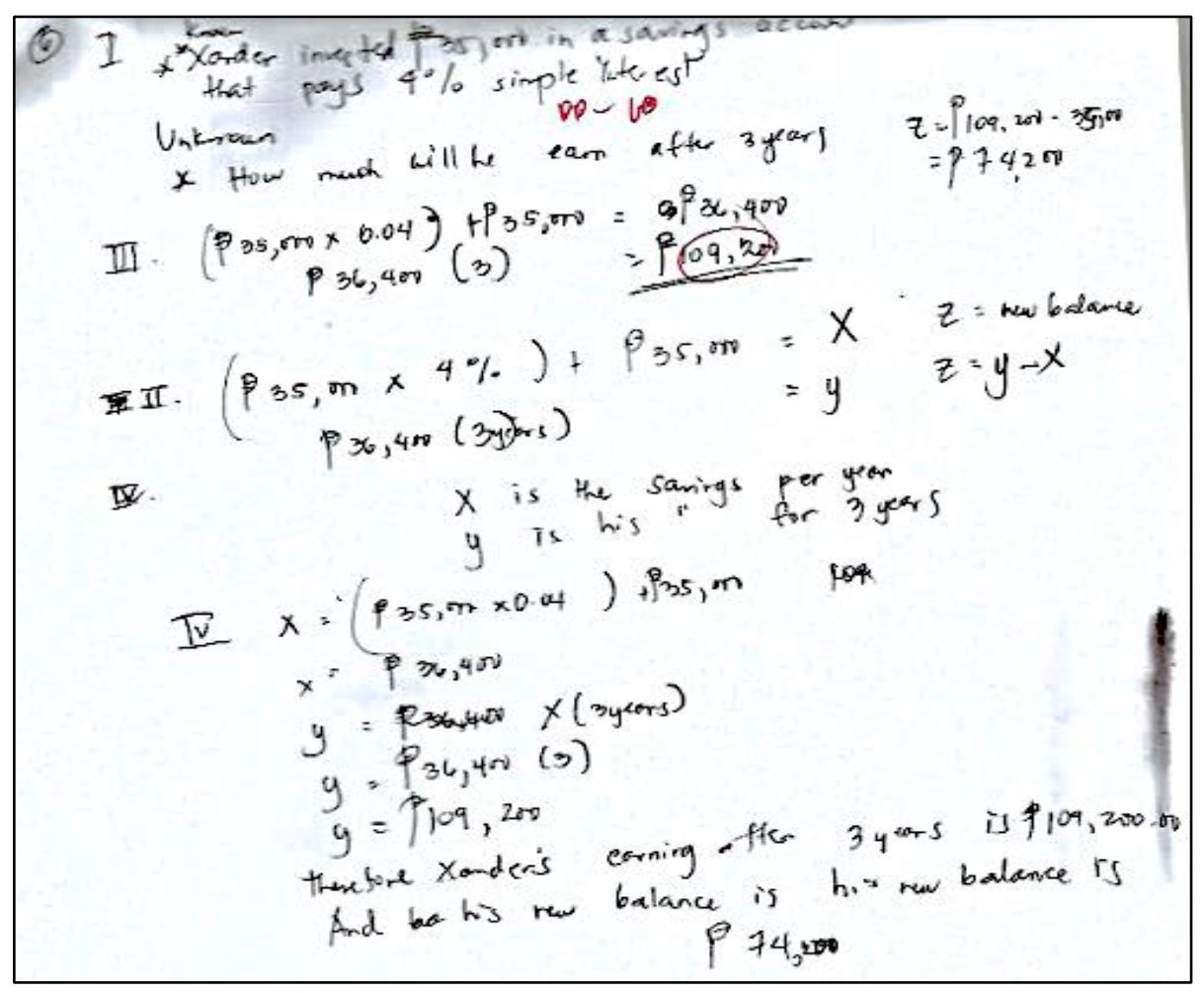

Figure 14: Solution of BS-ABE-A6

Figure 15 showed that the procedures went well, as can be seen from the solutions; however, s/he was not able to check whether the conditions given in the problem were satisfied or not.

8. The first of three numbers exceeds twice the second number by 4 , while the third number is twice the first. If the sum of the three number is 54 , find the numbers.

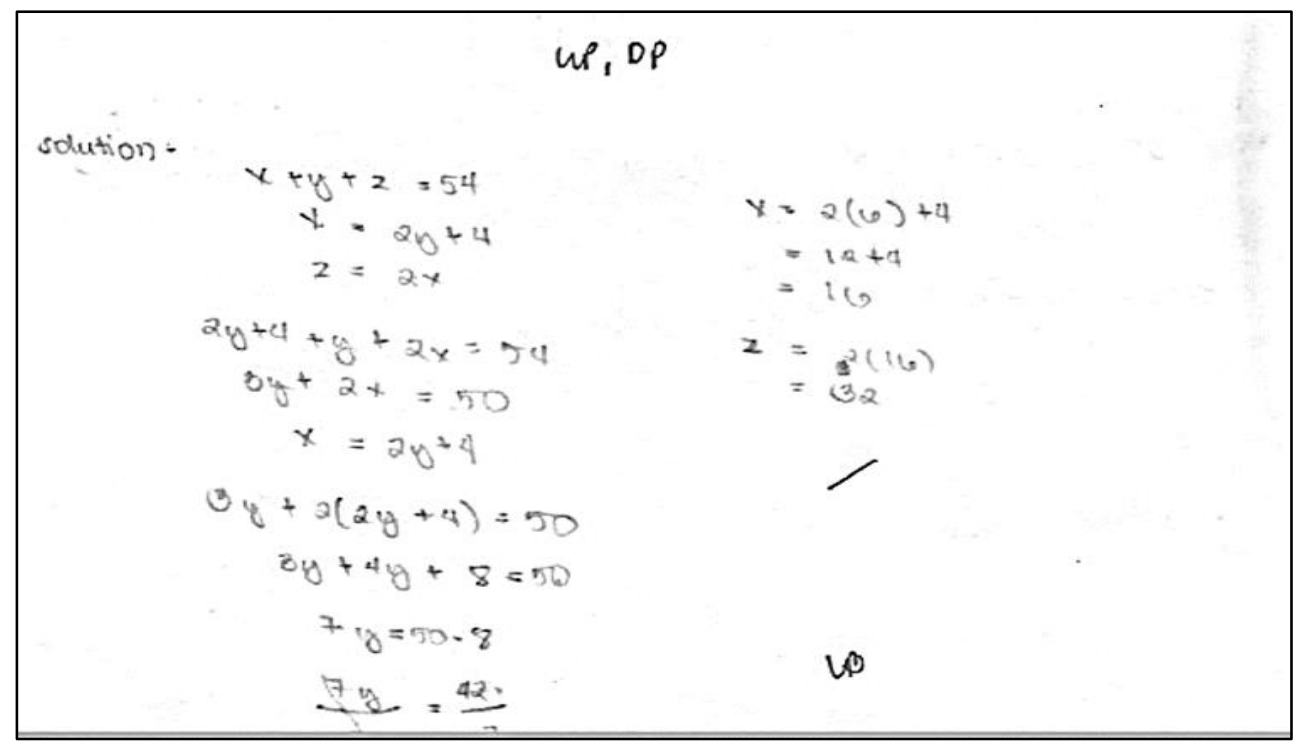

Figure 15: Solution of BSN-A1 
A summary of the common difficulties classified, according to sex and the academic program is presented in Table 5. It can be gleaned from the table that both males and females experienced the same type of difficulty in every phase of the problem-solving.

Table 5: Common problem-solving difficulties by sex and by phase

\begin{tabular}{|c|c|c|}
\hline Problem-Solving Phases & \multicolumn{2}{|c|}{ Sex } \\
\hline Understanding the Problem (UP) & Male & Female \\
\hline Devising a Plan (DP) & U1 & U1 \\
\hline Carrying Out the Plan (CP) & D1 & D1 \\
\hline Looking Back (LB) & C1 & C1 \\
\hline & L2 & L2 \\
\hline
\end{tabular}

Similarly, it can be seen in Table 6 that the majority of the students in the STEMrelated academic programs had difficulties in U2, D1, C1 and L2; while the majority of the students in the non-STEM related academic programs had difficulties in U1, D1, C1 and L2.

Table 6: Common problem-solving difficulties by academic program by phase

\begin{tabular}{|c|c|c|c|c|c|c|c|c|c|}
\hline \multirow{3}{*}{$\begin{array}{c}\text { Problem-Solving } \\
\text { Phases }\end{array}$} & \multicolumn{9}{|c|}{ Academic Programs } \\
\hline & \multicolumn{6}{|c|}{ STEM-Related } & \multicolumn{3}{|c|}{ Non-STEM-Related } \\
\hline & $\begin{array}{l}\text { BS- } \\
\text { ABE }\end{array}$ & BSCE & $\begin{array}{l}\text { BS- } \\
\text { ChE }\end{array}$ & BSM & $\begin{array}{l}\text { BS- } \\
\text { Met }\end{array}$ & BSN & $\begin{array}{l}\text { BA- } \\
\text { Com }\end{array}$ & $\begin{array}{c}\text { BS- } \\
\text { Econ }\end{array}$ & $\begin{array}{l}\text { BS- } \\
\text { Soc }\end{array}$ \\
\hline $\begin{array}{l}\text { Understanding } \\
\text { the Problem (UP) }\end{array}$ & U1 & U1 & $\mathrm{U} 2$ & U2 & U2 & $\mathrm{U} 2$ & U1 & U1 & U1 \\
\hline $\begin{array}{l}\text { Devising a Plan } \\
\text { (DP) }\end{array}$ & D1 & D1 & D1 & D2 & D1 & D1 & D1 & D1 & D1 \\
\hline $\begin{array}{l}\text { Carrying out the } \\
\text { Plan (CP) }\end{array}$ & $\mathrm{C} 1$ & $\mathrm{C} 1$ & $\mathrm{C} 1$ & $\mathrm{C} 2$ & $\mathrm{C} 1$ & $\mathrm{C} 2$ & $\mathrm{C} 1$ & C1 & $\mathrm{C} 1$ \\
\hline $\begin{array}{l}\text { Looking Back } \\
\text { (LB) }\end{array}$ & L2 & L2 & L2 & L2 & L2 & L2 & L2 & L2 & L2 \\
\hline
\end{tabular}

\subsection{Coping Strategies in the Different Phases of Problem-Solving}

There were 43 strategies that were elicited in the coping-strategy questionnaire. Each coping strategy was coded by using acronyms indicative of the problemsolving phase, where it belonged. For instance, the acronym UP1 is used to refer to the first strategy in the understanding of the problem phase (UP). Of the 43 identified strategies, 32 were problem-focused and 11 were emotion-focused. There were 10 strategies each, for the UP and the DP phases respectively, 12 for the $\mathrm{CP}$ phase and 11 for the LB phase. 
Table 7a: Coping strategies in the "understanding the plan phase"

\begin{tabular}{|c|c|c|}
\hline $\begin{array}{l}\text { Understanding the } \\
\text { Problem }\end{array}$ & Coping Strategies & Code \\
\hline \multirow{9}{*}{ Problem-Focused } & $\begin{array}{l}\text { recalled and/or applied basic facts/principles/stock } \\
\text { knowledge }\end{array}$ & UP1 \\
\hline & $\begin{array}{l}\text { understood fully, analyzed and listed/enumerated } \\
\text { all the given information and/or thought } \\
\text { critically/logically giving the focus on the } \\
\text { problem/needed focus }\end{array}$ & UP2 \\
\hline & $\begin{array}{l}\text { familiarization of terminologies using online } \\
\text { references and/or non-online references }\end{array}$ & UP3 \\
\hline & re-read/re-write the problem and the identified clues & UP5 \\
\hline & $\begin{array}{l}\text { rephrase/translated the sentence in one's own } \\
\text { words/grammar construction }\end{array}$ & UP6 \\
\hline & $\begin{array}{l}\text { asked seatmates/friends/teacher/tutor to help } \\
\text { explain/solve (assistance) }\end{array}$ & UP7 \\
\hline & $\begin{array}{l}\text { looked for more exercises in books, and read books } \\
\text { related to the problem at hand/more exposure }\end{array}$ & UP8 \\
\hline & reviewed old notes/lectures taught by the teacher & UP9 \\
\hline & listened attentively to the teacher & UP10 \\
\hline Emotion-Focused & ignored & UP4 \\
\hline
\end{tabular}

Table 7b: Coping strategies in the "devising a plan phase"

\begin{tabular}{|c|c|c|}
\hline Devising a Plan & Coping Strategies & Code \\
\hline \multirow{9}{*}{ Problem-Focused } & $\begin{array}{l}\text { recalled and/or applied related strategies/concepts } \\
\text { previously studied/stock knowledge to real-life } \\
\text { situations }\end{array}$ & DP1 \\
\hline & $\begin{array}{l}\text { understood fully, analyzed/thought through } \\
\text { critically and pondered on what the formula would be }\end{array}$ & DP2 \\
\hline & searched online for some strategies/related problems & DP3 \\
\hline & $\begin{array}{lllll}\begin{array}{l}\text { proceeded in creating } \\
\text { strategy/plan/formulas }\end{array} & \text { one's } & \text { own } \\
\end{array}$ & DP4 \\
\hline & performed trial-and-error with plans & DP5 \\
\hline & $\begin{array}{l}\text { organized information expressing the variables and } \\
\text { the other numbers connecting them to a concept }\end{array}$ & DP6 \\
\hline & $\begin{array}{l}\text { asked friends/teacher/tutor to help explain/solve } \\
\text { (assistance) }\end{array}$ & DP7 \\
\hline & $\begin{array}{l}\text { looked for more exercises in books and read books } \\
\text { related to the problem at hand/more } \\
\text { exposure/needed more problem-solving exercises }\end{array}$ & DP8 \\
\hline & needed computing gadgets & DP9 \\
\hline Emotion-Focused & did best to advance the study & DP10 \\
\hline
\end{tabular}


Table 7c: Coping strategies in the "carrying out the plan phase"

\begin{tabular}{|c|c|c|}
\hline $\begin{array}{l}\text { Carrying out the } \\
\text { Plan }\end{array}$ & Coping Strategies & Code \\
\hline \multirow{7}{*}{ Problem-Focused } & $\begin{array}{l}\text { understood fully, analyzed/thought critically and } \\
\text { solved the problem carefully/self-study; applied plan } \\
\text { to answer the problem by oneself }\end{array}$ & $\mathrm{CP} 1$ \\
\hline & $\begin{array}{l}\text { With the formulas as guides, one was able to make } \\
\text { substitutions/computations; but one needed } \\
\text { computing gadgets }\end{array}$ & $\mathrm{CP} 2$ \\
\hline & $\begin{array}{l}\text { watched YouTube/online applications / tutorials on } \\
\text { the process of computations }\end{array}$ & $\mathrm{CP} 3$ \\
\hline & learned/reviewed the process/computations & $\mathrm{CP} 4$ \\
\hline & performed trial-and-error approach & CP6 \\
\hline & $\begin{array}{l}\text { asked friends/teacher/tutor to help explain further } \\
\text { the process/computation/copied from seatmate }\end{array}$ & $\mathrm{CP7}$ \\
\hline & $\begin{array}{l}\text { needed to read more books/references and lots of } \\
\text { problem-solving exercises/more practice/ more } \\
\text { exposure }\end{array}$ & CP8 \\
\hline \multirow{5}{*}{ Emotion-Focused } & questioned oneself on how to solve it & CP5 \\
\hline & just overcame through positivity & CP9 \\
\hline & shared feelings with someone & CP10 \\
\hline & Ignored & CP11 \\
\hline & Talk and pray & CP12 \\
\hline
\end{tabular}

Table 7d: Coping strategies in the "looking-back phase"

\begin{tabular}{|c|l|l|}
\hline $\begin{array}{c}\text { Looking } \\
\text { Back }\end{array}$ & \multicolumn{1}{|c|}{ Coping Strategies } & \multicolumn{1}{|c|}{ Code } \\
\hline \multirow{5}{*}{$\begin{array}{c}\text { Problem- } \\
\text { Focused }\end{array}$} & rechecked/re-evaluated whether the answer was correct & LB1 \\
\cline { 2 - 3 } & $\begin{array}{l}\text { understood/analyzed the problem and more/self-study } \\
\text { to the problem at hand/more exposure }\end{array}$ & LB2 \\
\cline { 2 - 3 } & be objective in formulating the equations & LB8 \\
\cline { 2 - 3 } & performed trial and error & LB4 \\
\cline { 2 - 3 } & needed English-language skills & LB5 \\
\cline { 2 - 3 } & $\begin{array}{l}\text { asked friends/teacher/tutor to help explain the whole } \\
\text { process/ sought assistance from others }\end{array}$ & LB7 \\
\hline \multirow{5}{*}{$\begin{array}{l}\text { Emotion- } \\
\text { Focused }\end{array}$} & $\begin{array}{l}\text { thought that things would get better; thought that one } \\
\text { would get mature enough to handle the problems next time, } \\
\text { and not get confused with questions that have easy solutions }\end{array}$ & LB3 \\
\cline { 2 - 3 } & believing in one's own self-onfidence & LB9 \\
\cline { 2 - 3 } & concluded briefly & LB10 \\
\cline { 2 - 3 } & Ignored & LB1 \\
\hline
\end{tabular}

\subsubsection{Coping Strategies by Sex and by Phase}

Table 8 shows the top three coping strategies utilized by the students in each of the phases. The majority of the students in both sexes revealed that they utilized the same coping strategies for the UP, DP and CP phases. On the other hand, the majority of the female students preferred the coping strategy LB1, while the majority of the male respondents employed LB3 for the males in the LB phase. 
These strategies are all classified under problem-focused coping strategies, except LB3, which is an emotion-focused coping strategy.

Table 8: Top three common coping strategies by sex and by phase

\begin{tabular}{|c|c|c|c|}
\hline \multirow{2}{*}{$\begin{array}{c}\text { Phases of } \\
\text { Problem-Solving }\end{array}$} & \multirow{2}{*}{ Coping Strategies } & \multicolumn{2}{|c|}{ Sex } \\
\hline & & Male & Female \\
\hline \multirow{5}{*}{$\begin{array}{l}\text { Understanding the } \\
\text { Problem (UP) }\end{array}$} & \multirow{4}{*}{ Problem-Focused } & UP2* & UP2* \\
\hline & & UP3 & UP3 \\
\hline & & & UP5 \\
\hline & & UP8 & UP8 \\
\hline & Emotion-Focused & & \\
\hline \multirow{5}{*}{$\begin{array}{l}\text { Devising a Plan } \\
\text { (DP) }\end{array}$} & \multirow{4}{*}{ Problem-Focused } & & DP2 \\
\hline & & DP3 & DP3 \\
\hline & & DP4 & \\
\hline & & DP8* & DP8* \\
\hline & Emotion-Focused & & \\
\hline \multirow{4}{*}{$\begin{array}{l}\text { Carrying Out the } \\
\text { Plan (CP) }\end{array}$} & \multirow{3}{*}{ Problem-Focused } & CP1 & CP1 \\
\hline & & & $\mathrm{CP} 2$ \\
\hline & & $\begin{array}{l}\text { CP7* } \\
\text { CP8 }\end{array}$ & $\mathrm{CP} 7 *$ \\
\hline & Emotion-Focused & & \\
\hline \multirow{3}{*}{ Looking Back (LB) } & \multirow[t]{2}{*}{ Problem-Focused } & LB1 & LB1* \\
\hline & & & LB2 \\
\hline & Emotion-Focused & $\begin{array}{l}\mathrm{LB3}^{*} \\
\text { LB9 }\end{array}$ & LB3 \\
\hline
\end{tabular}

* The coping strategy utilized by the majority

Table 9a presents the top three common coping strategies of the different academic programs in the STEM track. Across programs, the majority of the students preferred the strategies of UP2, DP8, CP7 and LB1 in each of the different phases, all categorized as problem-focused coping strategies. It is worth noting, however, that the majority of the students in the BS in Civil Engineering, BS in Mathematics and BS in Nursing, applied LB3, which is an emotion-focused coping strategy. 
Table 9a: Top three common coping strategies by STEM-related academic Programs by phase

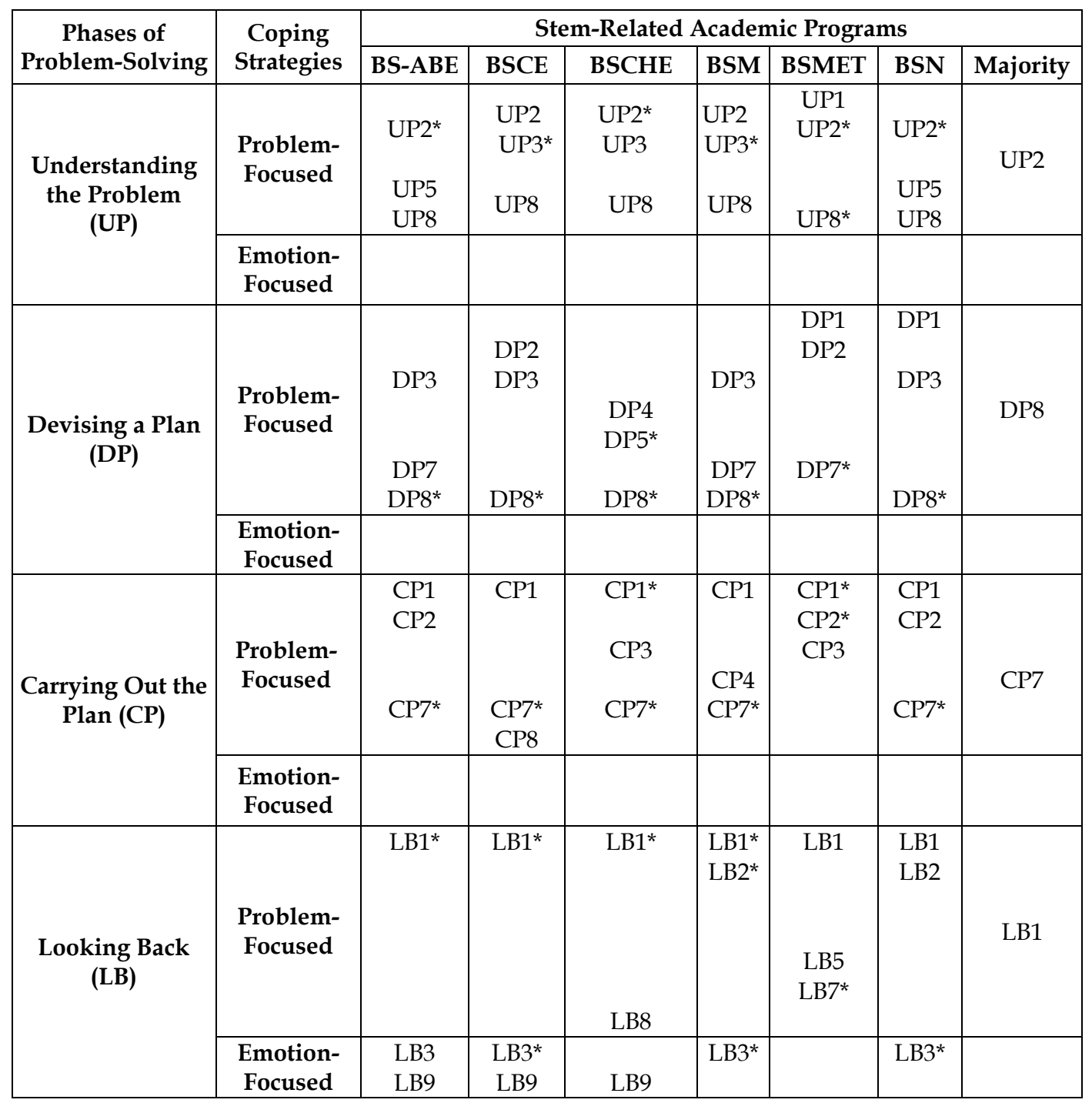

* Top 3 coping strategies utilized by the majority

For the three non-STEM-related academic programs in Table 9b, students preferred the strategies of UP2, DP8, CP7 and LB3. It is to be noted that LB3 is an emotion-focused coping strategy, which was preferred by the majority of the students in the said academic program. 
Table 9b: Top three common coping strategies by non-STEM-related academic programs by phase

\begin{tabular}{|c|c|c|c|c|c|}
\hline \multirow{2}{*}{$\begin{array}{c}\text { Phases of } \\
\text { Problem-Solving }\end{array}$} & \multirow{2}{*}{$\begin{array}{l}\text { Coping } \\
\text { Strategies }\end{array}$} & \multicolumn{4}{|c|}{ Non-Stem-Related Academic Programs } \\
\hline & & $\begin{array}{c}\text { BA } \\
\text { Com }\end{array}$ & $\begin{array}{c}\text { BS } \\
\text { Econ }\end{array}$ & BS-Soc & Majority \\
\hline \multirow{3}{*}{$\begin{array}{l}\text { Understanding } \\
\text { the Problem (UP) }\end{array}$} & \multirow[t]{2}{*}{$\begin{array}{l}\text { Problem- } \\
\text { Focused }\end{array}$} & $\begin{array}{l}\text { UP1 } \\
\text { UP2* }\end{array}$ & $\begin{array}{l}\text { UP2* } \\
\text { UP3 }\end{array}$ & $\begin{array}{l}\text { UP2* } \\
\text { UP3 }\end{array}$ & UP2 \\
\hline & & & UP8 & UP8 & \\
\hline & $\begin{array}{l}\text { Emotion- } \\
\text { Focused }\end{array}$ & & & & \\
\hline \multirow{4}{*}{$\begin{array}{l}\text { Devising a Plan } \\
\text { (DP) }\end{array}$} & \multirow{3}{*}{$\begin{array}{l}\text { Problem- } \\
\text { Focused }\end{array}$} & DP2 & DP2 & & \\
\hline & & $\begin{array}{l}\text { DP4* } \\
\text { DP6 }\end{array}$ & DP5 & DP3 & DP8 \\
\hline & & & DP8* & DP8* & \\
\hline & $\begin{array}{l}\text { Emotion- } \\
\text { Focused }\end{array}$ & & & & \\
\hline \multirow{4}{*}{$\begin{array}{l}\text { Carrying Out the } \\
\text { Plan (CP) }\end{array}$} & \multirow{3}{*}{$\begin{array}{l}\text { Problem- } \\
\text { Focused }\end{array}$} & $\mathrm{CP} 1^{*}$ & $\mathrm{CP1}$ & $\mathrm{CP} 1$ & \\
\hline & & CP3 & CP6 & $\mathrm{CP} 3$ & CP7 \\
\hline & & $\mathrm{CP}^{*}$ & $\mathrm{CP7}^{*}$ & $\mathrm{CP}^{*}$ & \\
\hline & $\begin{array}{l}\text { Emotion- } \\
\text { Focused }\end{array}$ & & & & \\
\hline \multirow{3}{*}{ Looking Back (LB) } & & LB1* $^{*}$ & & LB1 & \\
\hline & $\begin{array}{l}\text { Problem- } \\
\text { Focused }\end{array}$ & LB7 & $\begin{array}{l}\text { LB5 } \\
\text { LB7* } \\
\text { LB8 }\end{array}$ & $\begin{array}{l}\text { LB5 } \\
\text { LB7 }\end{array}$ & \\
\hline & $\begin{array}{l}\text { Emotion- } \\
\text { Focused }\end{array}$ & LB3 $^{*}$ & & $\begin{array}{l}\text { LB3* }^{*} \\
\text { LB99 }\end{array}$ & LB3 \\
\hline
\end{tabular}

* Top 3 coping strategies utilized by the majority

Comparing the data presented above, it can be summarized that the two groups utilized the same coping strategies from the UP phase until the CP phase. The LB phase, on the other hand, shows that the two academic programs preferred dissimilar coping strategies; LB1 for the STEM-related and LB3 for the non-STEMrelated programs, respectively. 


\subsection{Model Development}

After careful examination of the associations between and among the variables in this study, the following models were developed.

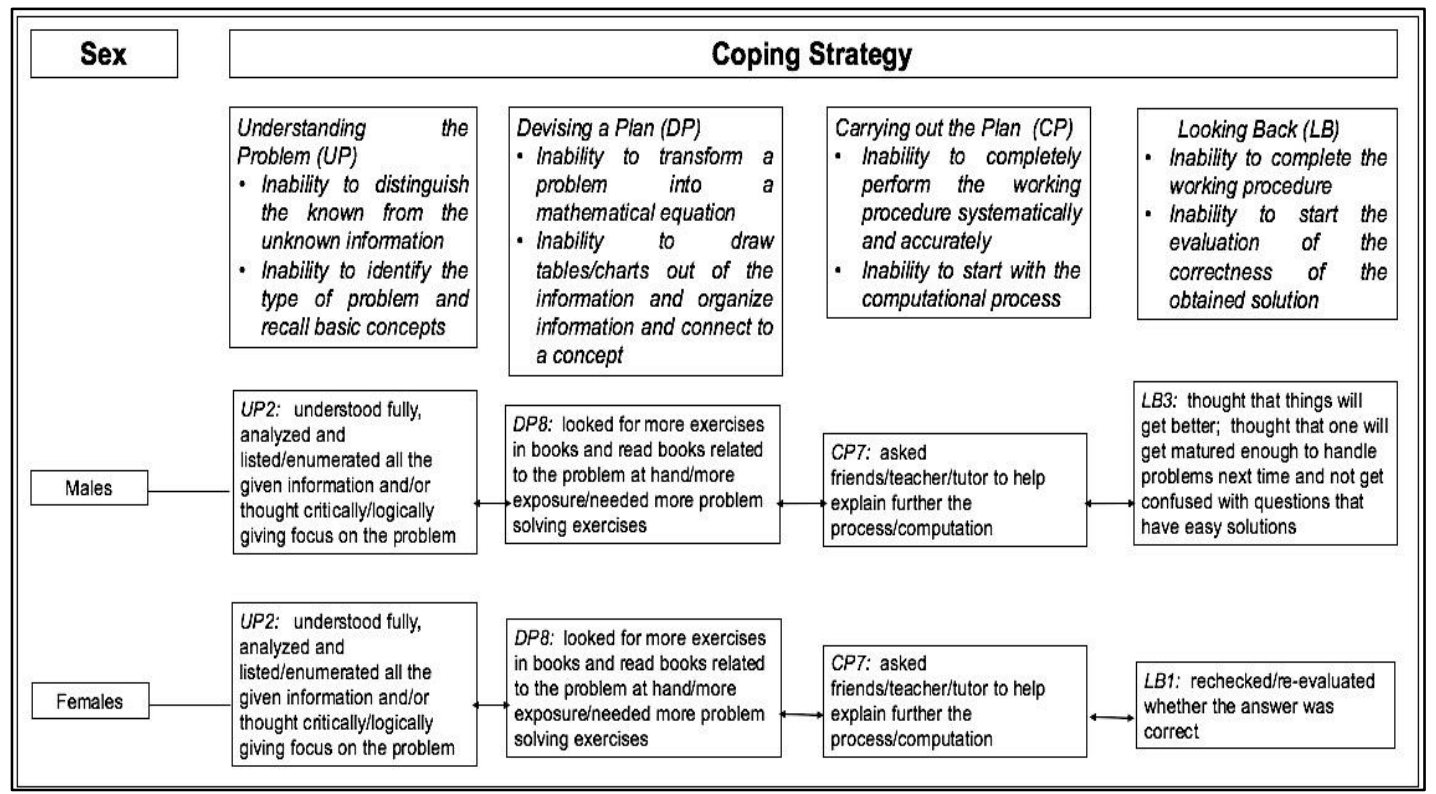

Figure 16: Coping Strategy by Sex by Phase Model

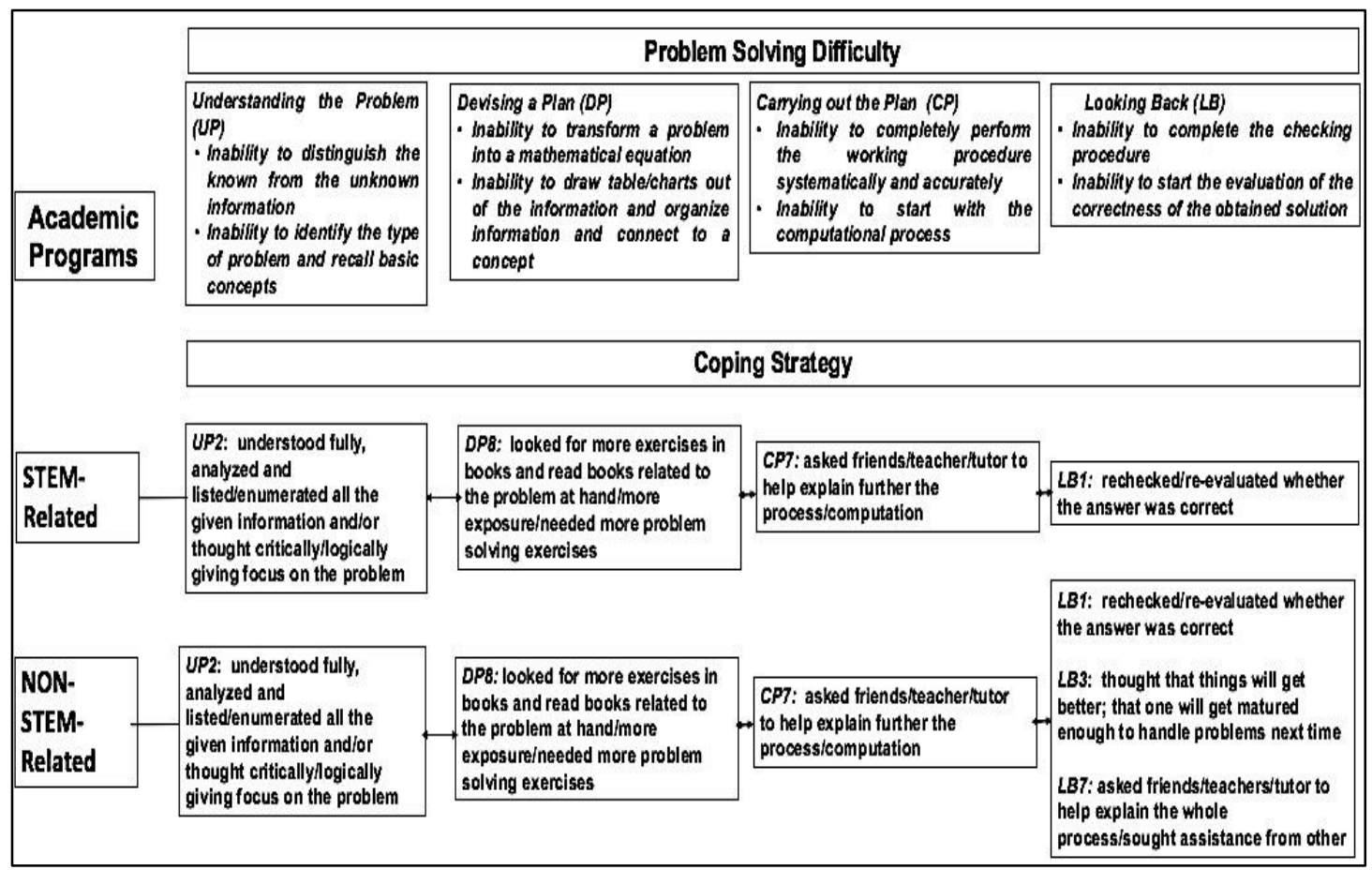

Figure 17: Coping Strategy by Academic Program (in General) by Phase 


\begin{tabular}{|c|c|c|c|c|}
\hline \multirow{2}{*}{$\begin{array}{l}\text { Academic } \\
\text { Programs }\end{array}$} & \multicolumn{4}{|c|}{ Problem Solving Difficulty } \\
\hline & \begin{tabular}{|l|} 
Understanding the Problem (UP) \\
- Inability to distinguish the known \\
from the unknown information \\
- Inablity to identify the type of \\
problem and recall basic concepts
\end{tabular} & \begin{tabular}{|l|} 
Devising a Plan (DP) \\
- Inabtithy to transform a problem into a \\
mathematicatequation \\
- Inability to draw tables/charts out of the \\
information and arganiza information and \\
connect to a concept
\end{tabular} & \begin{tabular}{|l|} 
Carrying out the Plan (CF) \\
- Inability to completely perform the \\
working procedure systematically and \\
accurately \\
inability to start with the computational \\
process
\end{tabular} & 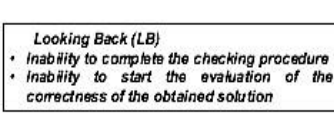 \\
\hline STEM- & \multicolumn{4}{|c|}{ Coping Strategy } \\
\hline BS-ABE & \begin{tabular}{|l|} 
UP2: understood fully, analyzed and \\
listed/enumerated all the given \\
information and/or thought \\
criticallyllogically giving focus on the \\
problem
\end{tabular} & $\begin{array}{l}\text { DP8: looked for more exercises in books } \\
\text { and read books related to the problem at } \\
\text { handlmore exposure/needed more } \\
\text { problem solving exercises }\end{array}$ & $\begin{array}{l}\text { CP7: asked friends/teacheritutor to } \\
\text { help explain further the } \\
\text { process/computation }\end{array}$ & $\begin{array}{l}\text { LB1: rechecked/re-vvaluated whether the } \\
\text { answer was correct }\end{array}$ \\
\hline BS-CE & $\begin{array}{l}\text { UP3: familiarization of terminologies } \\
\text { using online references and/or non- } \\
\text { online resources }\end{array}$ & $\begin{array}{l}\text { DP8: looked for more exercises in books } \\
\text { and read books related to the problem at } \\
\text { handimore exposure/needed more } \\
\text { problem solving exercises }\end{array}$ & $\begin{array}{l}\text { CP7: asked friends/teacherkutor to } \\
\text { help explain further the } \\
\text { processicomputation }\end{array}$ & $\begin{array}{l}\text { LB1: recheckedre-evaluated whether the } \\
\text { answer was correct } \\
\text { L83: thought that things will get better; } \\
\text { that one will get matured enough to handle } \\
\text { problems next time }\end{array}$ \\
\hline & $\begin{array}{l}\text { UP2: understood fully, analyzed and } \\
\text { listed/enumerated all the given } \\
\text { information and/or thought } \\
\text { critically/logically giving focus on the } \\
\text { problem }\end{array}$ & $\begin{array}{l}\text { DP5: performed trial and error with } \\
\text { plans } \\
\text { DP8: looked for more exercises in books } \\
\text { and read books related to the problem st } \\
\text { handimore exposurelneeded more } \\
\text { problem solving exercises }\end{array}$ & $\begin{array}{l}\text { CP1: understood fully, } \\
\text { analyzed/thought critically and } \\
\text { solved the problem carefully/self- } \\
\text { study ; applied plan to answer the } \\
\text { problem by oneself }\end{array}$ & $\begin{array}{l}\text { LB1: recheckedire-evaluated whether the } \\
\text { answer was correct }\end{array}$ \\
\hline \multirow[t]{2}{*}{ BS-MATH } & $\begin{array}{l}\text { UP3: familiarization of terminologies } \\
\text { using online references and/or non- } \\
\text { online references }\end{array}$ & $\begin{array}{l}\text { DP8: looked for more exercises in books } \\
\text { and read books related to the problem at } \\
\text { handimore exposure/needed more } \\
\text { problem solving exercises }\end{array}$ & $\begin{array}{l}\text { CP7: asked friends/teacherkutor to } \\
\text { help explain further the } \\
\text { processicomputation }\end{array}$ & \multirow{2}{*}{$\begin{array}{l}\text { LB1: rechecked/re-evaluated whether the } \\
\text { answer was correct } \\
\text { LB2: understood/analyzed the problem } \\
\text { more/self-study } \\
\text { LB3:thought that things will get better; } \\
\text { thought that one will get matured enough } \\
\text { to handle problems next time and not get } \\
\text { confused with questions that have easy } \\
\text { solutions }\end{array}$} \\
\hline & \multirow{3}{*}{\begin{tabular}{|l|} 
UP2: understood fully, analyzed and \\
listed/enumerated all the given \\
information and/or thought \\
critically/logically giving focus on the \\
problem \\
UP8: looked for more exercises in \\
books and read books related to the \\
problem at hand/more exposure \\
\end{tabular}} & & \multirow{3}{*}{$\begin{array}{l}\text { CP1: understood fully, } \\
\text { analyzed/thought critically and } \\
\text { solved the problem carefullyself- } \\
\text { study ; applied plan to answer the } \\
\text { problem by oneself } \\
\text { CP2: With the formulas as guides, } \\
\text { was ablo to make } \\
\text { subsitutions/computations; } \\
\text { needed computing gadgets }\end{array}$} & \\
\hline BS-METEO & & \begin{tabular}{|l|} 
DP7: asked friends/leacher/tutor to help \\
explain/solve (assistance)
\end{tabular} & & \multirow[t]{2}{*}{$\begin{array}{l}\text { LB7: asked friends/teacheritutor to help } \\
\text { explain the whole process/sought } \\
\text { assistance from others }\end{array}$} \\
\hline & & & & \\
\hline
\end{tabular}

Figure 18: Coping Strategy by Academic Program (STEM-Related) by Phase

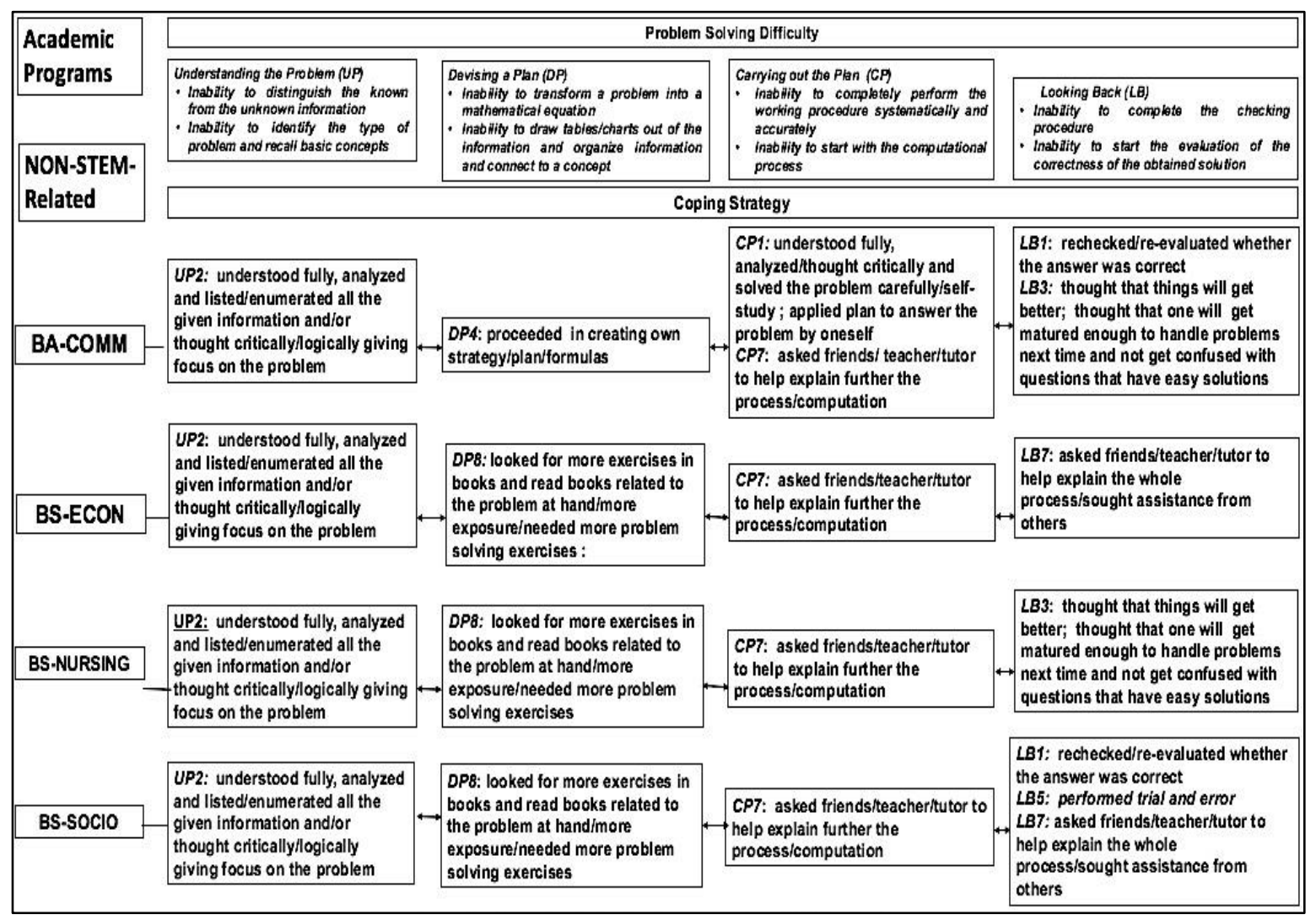

Figure 19: Coping Strategy by Academic Program (non STEM-related) by Phase Model 


\subsection{Model Validation}

Addressing the difficulties of the students through their coping strategies was one of the aims of the study, hence, validation of the models had to be undertaken. Purposive sampling was done to select the respondents that would be included in the validation group; thus, factors like availability of the respondents, together with their coping strategies that matched those presented in the models developed, were taken into account. Eight male respondents and 10 female respondents were sampled for validating the "Coping Strategies by Sex by Phase Model".

In Figure 20, the pretest of Male \#1 had pre-identified difficulties, namely; DP, CP and LB. However, the post-test revealed that there was a reduction in his phase and a difficulty after incorporating the coping strategy UP2. Considering the eight males that were sampled, it can be observed in the post-test that there had been a reduction in their pre-identified difficulties.

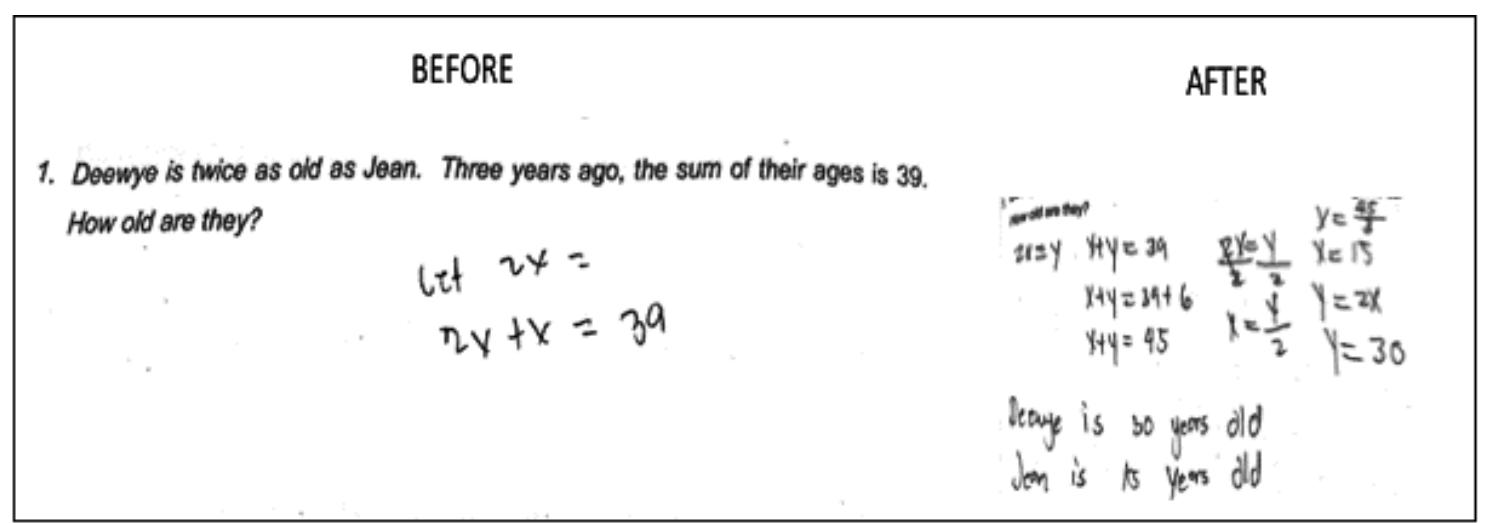

Figure 20: Pre-Post Solution of Male \#1 Difficulty/ies: DP, CP, LB;

Coping Strategy/ies: UP2

Focusing on the solution of the Male \#2 in the pretest in Figure 21, it can be seen that he was successful in deriving the answers for the requirements of the problem. But after looking for more exercises and reading more books with related problems (DP8), the student was able to check his derived values, and concluded consequently. Hence, the student's difficulty, which was looking back before was finally resolved in the validation stage. 


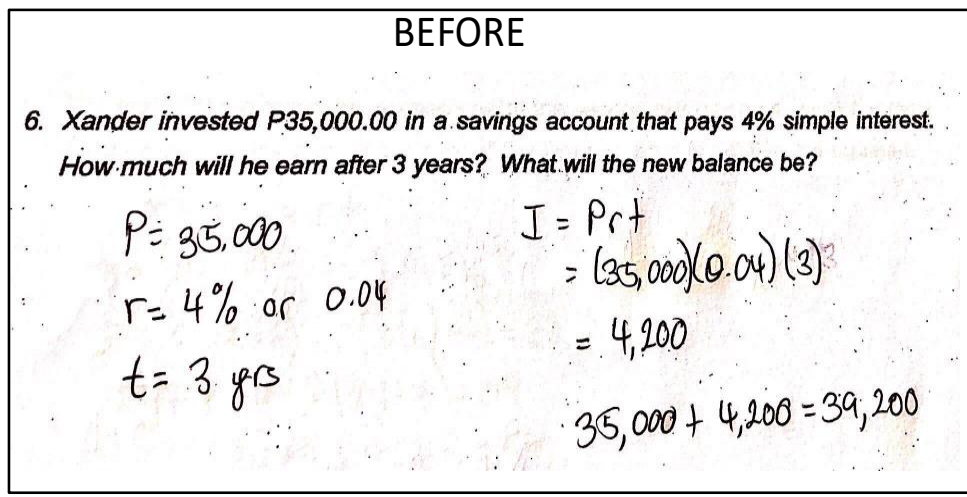

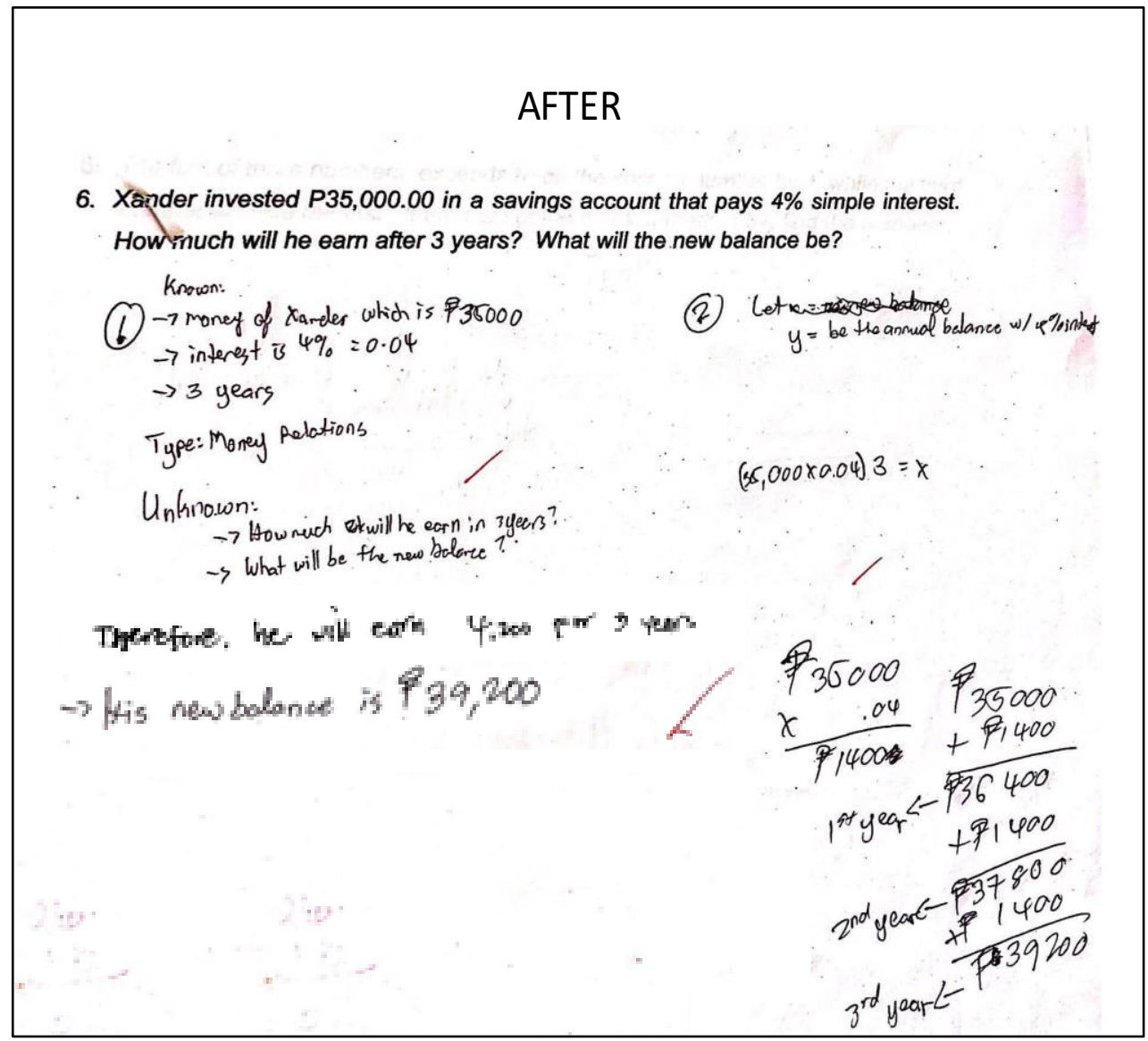

Figure 21: Pre-Post Solution of Male \#2

Difficulty/ies: LB; Coping Strategy: DP8

The student struggled in the looking-back (LB) phase (Figure 22). After utilizing the strategy of looking for more exercises and reading more books with related problems (DP8), the student was able to check with the correct computation and with a concluding statement. Generally, the student's difficulty, which is looking back before, was totally resolved after the validation stage. 


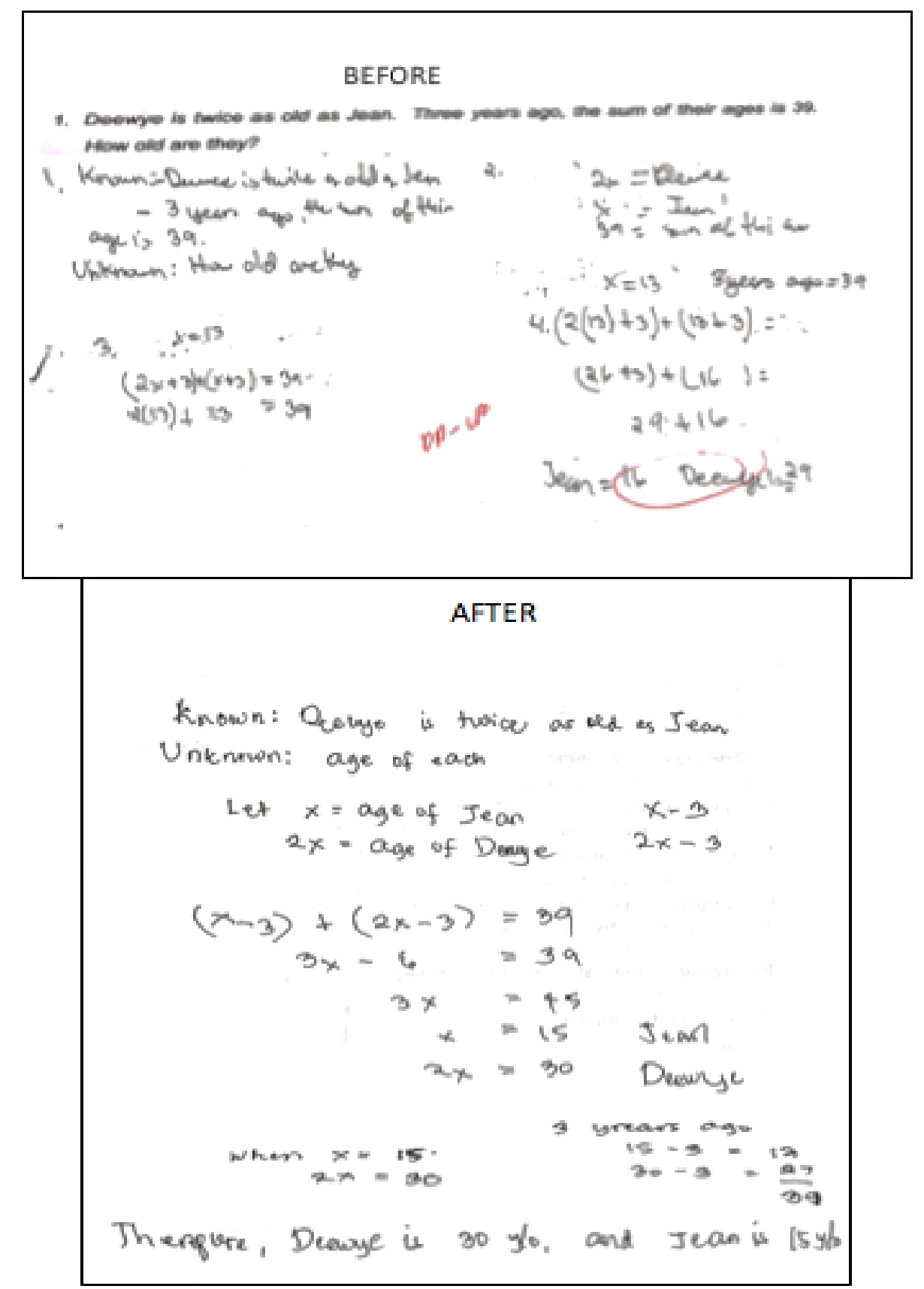

Figure 22: Pre-Post Solution of Male \#5 Difficulty: LB; Coping Strategy: DP8

A summary of the pre-post test results of the validation samples (males) is presented in Table 10, showing a reduction or a total eradication of the frequency of pre-identified difficulties. 
Table 10: Model validation of coping strategies of male students by phase

\begin{tabular}{|c|c|c|c|c|c|c|}
\hline $\begin{array}{c}\text { MALE } \\
\#\end{array}$ & \multicolumn{3}{|c|}{ Coping Strategies } & \multicolumn{2}{c|}{ Difficulty } \\
\hline & $\begin{array}{c}\text { Understan } \\
\text { ding the } \\
\text { Problem } \\
\text { (UP) }\end{array}$ & $\begin{array}{c}\text { Devising } \\
\text { a Plan } \\
\text { (DP) }\end{array}$ & $\begin{array}{c}\text { Carrying } \\
\text { out the } \\
\text { Plan (CP) }\end{array}$ & $\begin{array}{c}\text { Looking } \\
\text { Back } \\
\text { (LB) }\end{array}$ & Before & After \\
\hline 1 & UP2 & DP7 & CP8 & LB1 & DP, CP, LB & LB \\
\hline 2 & UP8 & DP8 & CP4 & LB2 & LB & - \\
\hline 3 & UP3 & DP8 & CP7 & LB10 & LB & - \\
\hline 4 & UP5 & DP8 & CP7 & LB4 & CP & - \\
\hline 5 & & DP8 & & & LB & - \\
\hline 6 & UP8 & DP8 & CP1 & LB3 & DP, CP, LB & CP, LB \\
\hline 7 & UP1 & DP1 & CP7 & LB1 & LB & - \\
\hline 8 & UP2 & DP8 & CP2 & LB1 & CP, LB & LB \\
\hline
\end{tabular}

Looking at the solution (Figure 23), the student failed in forming the mathematical equation (DP). She knew how to operate the equation she had formed, so that she even had a concluding statement. However, after seeking assistance from friends/teacher/tutor, she was able to form the correct mathematical equation. With this, her difficulties of devising a plan were resolved.

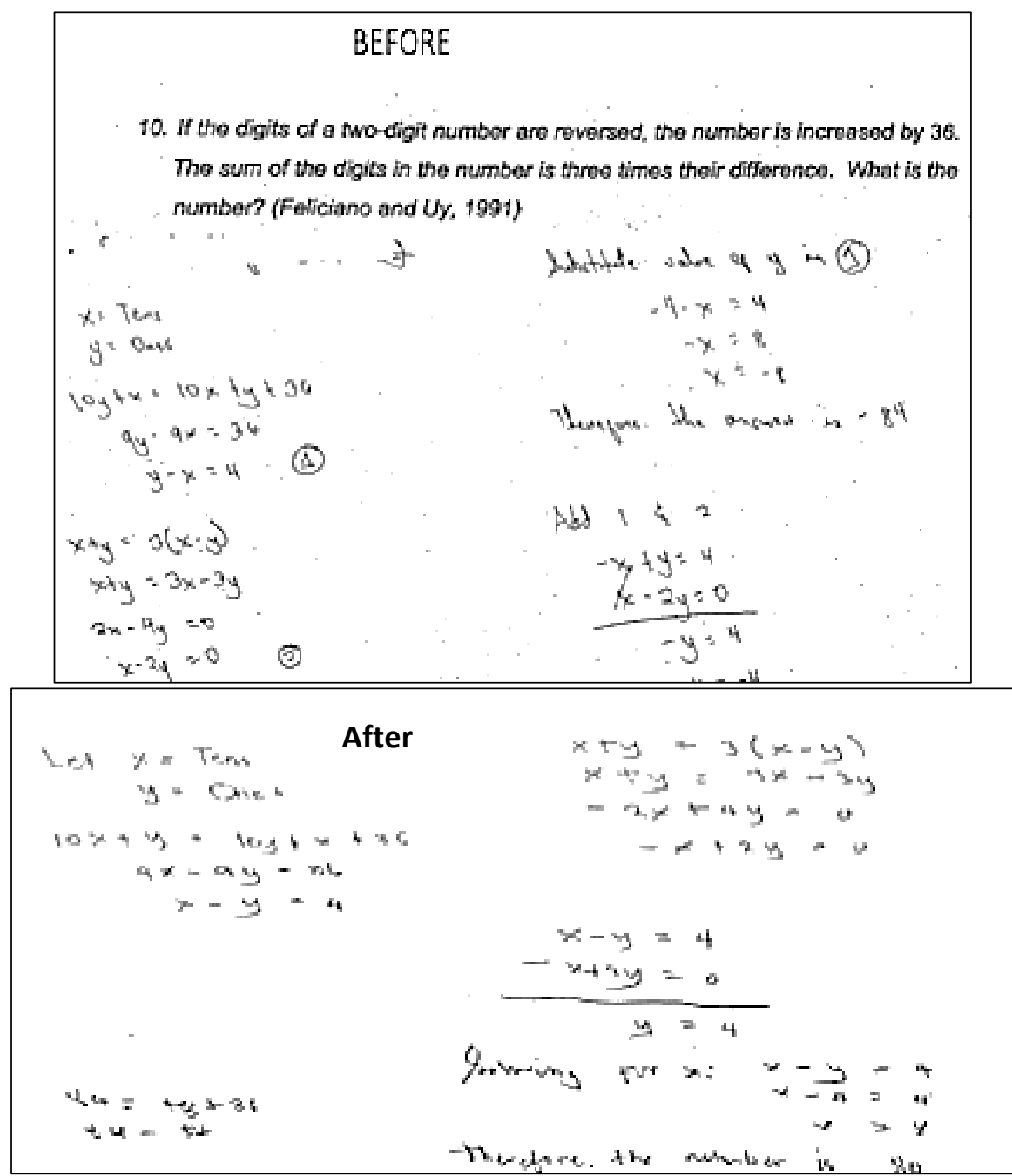

Figure 23: Pre-Post Solution of Female \#2;

Difficulty: DP; Coping Strategy: CP7 
This student (Figure 24) was able to perform only the first phase of the problemsolving. Then, after utilizing the strategies of looking for more exercises and reading more books with related problems (DP8), and by seeking assistance from friends/teacher/tutor (CP7), she was able to perform all the phases of the problem-solving. Hence, her difficulties were totally resolved.
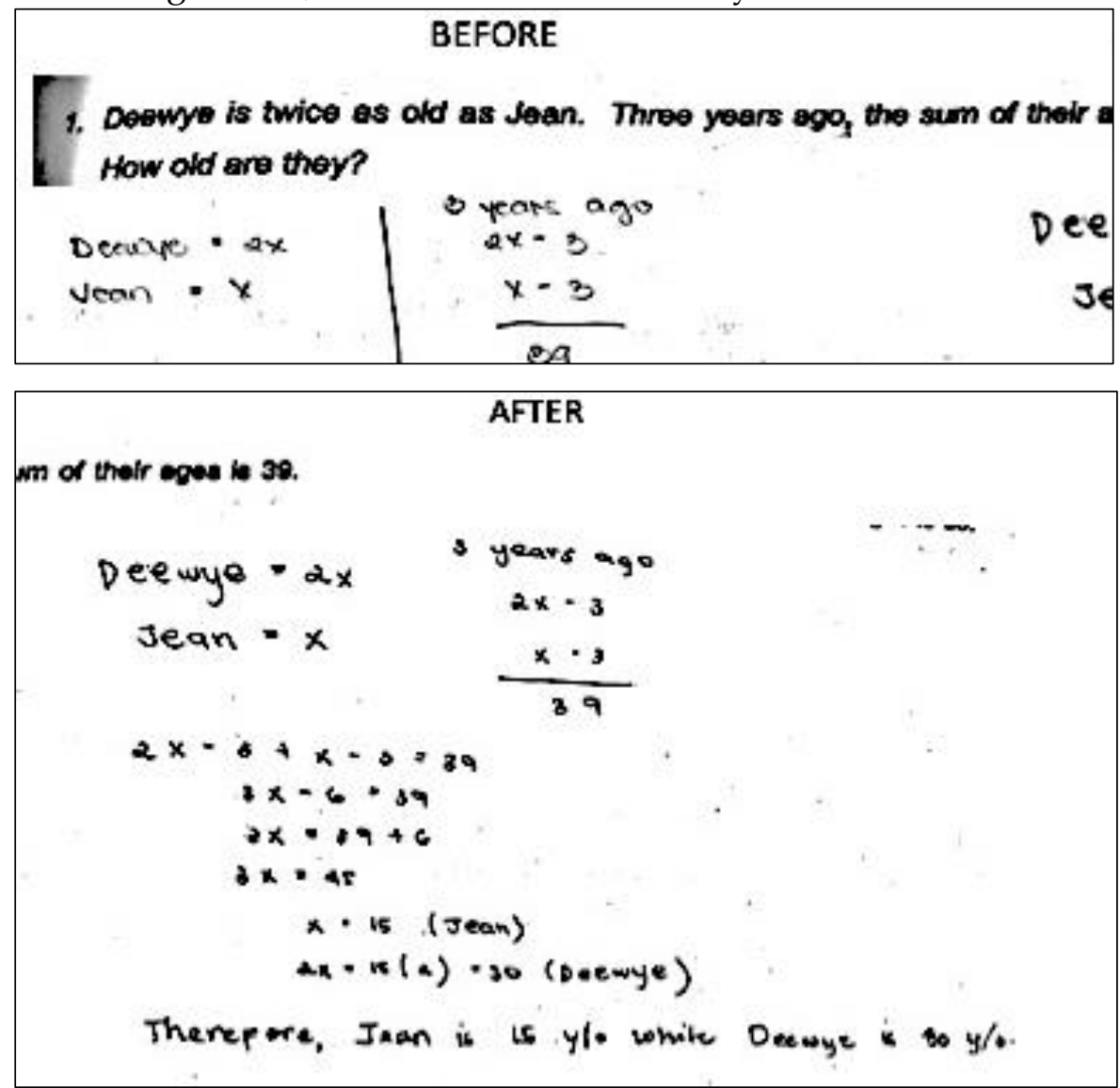

Figure 24: Pre-Post Solution of Female \#4; Difficulty/ies: DP, CP, LB Coping Strategy/ies: DP8, CP7

A summary of the pre-post test results of the validation samples (females) is presented in Table 1,1 showing a reduction or a total eradication of the frequency of pre-identified difficulties. 
Table 11: Model validation of coping strategies of female students by phase

\begin{tabular}{|c|c|c|c|c|c|c|}
\hline & \multicolumn{3}{|c|}{ Coping Strategies } & \multicolumn{2}{c|}{ Difficulty } \\
\hline FEMALE \# & $\begin{array}{c}\text { Understa } \\
\text { nding the } \\
\text { Problem } \\
\text { (UP) }\end{array}$ & $\begin{array}{c}\text { Devisin } \\
\text { g a Plan } \\
\text { (DP) }\end{array}$ & $\begin{array}{c}\text { Carrying } \\
\text { out the } \\
\text { Plan } \\
\text { (CP) }\end{array}$ & $\begin{array}{c}\text { Lookin } \\
\text { g Back } \\
\text { (LB) }\end{array}$ & Before & After \\
\hline 1 & UP2 & & CP7 & & DP, LB & LB \\
\hline 2 & UP3 & DP3 & CP7 & LB9 & DP & \\
\hline 3 & UP5 & DP8 & CP7 & LB9 & DP & - \\
\hline 4 & UP8 & DP8 & CP7 & LB3 & $\begin{array}{c}\text { DP, CP, } \\
\text { LB }\end{array}$ & - \\
\hline 5 & UP2 & DP4 & CP2 & LB1 & $\begin{array}{c}\text { DP, CP, } \\
\text { LB }\end{array}$ & - \\
\hline 6 & UP3 & DP8 & CP7 & LB9 & DP & \\
\hline 7 & UP3 & DP8 & CP7 & LB2 & $\begin{array}{c}\text { DP, CP, } \\
\text { LB }\end{array}$ & CP, LB \\
\hline 8 & UP5 & DP6 & CP7 & LB3 & CP & - \\
\hline 9 & UP3 & DP3 & CP7 & LB1 & CP, LB & CP \\
\hline 10 & UP1 & DP8 & CP7 & LB3 & LB & - \\
\hline
\end{tabular}

Lastly, Table 12 presents the respondents from each academic program with a reduced number of their pre-identified difficulties after the post-test.

Table 12: Model validation of coping strategies by academic program by phase

\begin{tabular}{|c|c|c|c|c|c|c|c|}
\hline \multirow[b]{2}{*}{$\begin{array}{l}\text { Academic } \\
\text { Program }\end{array}$} & \multicolumn{4}{|c|}{ Coping Strategies } & \multicolumn{2}{|c|}{ Difficulty } & \multirow[b]{2}{*}{$\begin{array}{c}\text { Exhibit } \\
\#\end{array}$} \\
\hline & (UP) & $(\mathrm{DP})$ & $(\mathrm{CP})$ & (LB) & Before & After & \\
\hline \multicolumn{8}{|c|}{ STEM-related } \\
\hline$\overline{B S-A B E}$ & UP2 & DP8 & CP7 & LB1 & & & \\
\hline BS-ABE-B6 & UP2 & DP7 & CPB & LB1 & $\mathrm{DP}, \mathrm{CP}, \mathrm{LB}$ & LB & $17(\mathrm{M})$ \\
\hline BS-ABE-A1 & UP2 & & CP7 & & DP, LB & LB & $25(F)$ \\
\hline BS-CE & UP3 & DP8 & CP7 & LB1;LB3 & & & \\
\hline BS-CE-A13 & UP5 & DP6 & CP7 & LB3 & $\mathrm{CP}$ & - & $32(F)$ \\
\hline BS-CE-B16 & UP3 & DP3 & $\mathrm{CP} 7$ & LB1 & CP, LB & $\mathrm{CP}$ & $33(\mathrm{~F})$ \\
\hline BS-CHEM E & UP2 & $\begin{array}{l}\text { DP5; } \\
\text { DP8 }\end{array}$ & $\mathrm{CP} 1 ; \mathrm{CP} 7$ & LB1 & & & \\
\hline BS-CHEM-15 & UP1 & DP1 & $\mathrm{CP} 7$ & LB1 & LB & - & $23(\mathrm{M})$ \\
\hline BS-CHEM-4 & UP5 & DP5 & CP6 & LB8 & LB & & $35(\mathrm{~F})$ \\
\hline BS-MATH & UP3 & DP8 & $\mathrm{CP} 7$ & $\begin{array}{c}\text { LB1; LB2; } \\
\text { LB3 }\end{array}$ & & & \\
\hline BS-MATH-18 & UP2 & DP4 & $\mathrm{CP} 2$ & LB1 & $\mathrm{DP}, \mathrm{CP}, \mathrm{LB}$ & - & $29(F)$ \\
\hline BS-MATH-4 & UP3 & DP8 & CP7 & LB9 & DP & - & $30(\mathrm{~F})$ \\
\hline BS-MATH-22 & & DP8 & & & LB & - & $21(M)$ \\
\hline BS-METEO & UP2;UPB & DP7 & CP1; CP2 & LB7 & & & \\
\hline BS-METEO-3 & UPB & DP8 & CP4 & LB2 & LB & & $18(\mathrm{M})$ \\
\hline BS-N & UP2 & DP8 & $\mathrm{CP} 7$ & LB3 & & & \\
\hline $\mathrm{BSN}-\mathrm{A} 30$ & UP1 & DP8 & $\mathrm{CP} 7$ & LB3 & LB & - & $34(\mathrm{~F})$ \\
\hline $\mathrm{BSN}-\mathrm{A} 33$ & UP2 & DP8 & $\mathrm{CP} 2$ & LB1 & CP, LB & - & $24(M)$ \\
\hline BSN-A36 & UP7 & DP7 & $\mathrm{CP} 7$ & LB4 & LB & & $37(\mathrm{M})$ \\
\hline \multicolumn{8}{|c|}{ NON-STEM-related } \\
\hline BA-COMM & UP2 & DP4 & $\mathrm{CP} 1 ; \mathrm{CP} 7$ & LB1; LB3 & & & \\
\hline BA-COMM-2 & UP5 & DP8 & CP7 & LB4 & $\mathrm{CP}$ & - & $20(M)$ \\
\hline BA-COMM-17 & UPB & DP8 & $\mathrm{CP} 7$ & LB3 & $\mathrm{DP}, \mathrm{CP}, \mathrm{LB}$ & - & $28(F)$ \\
\hline BA-COMM-4 & UP2 & DP1 & $\mathrm{CP} 2$ & LB1 & $\mathrm{DP}$ & & $36(\mathrm{~F})$ \\
\hline BS-ECON & UP2 & DP8 & $\mathrm{CP} 7$ & LB7 & & & \\
\hline BS-ECON-22 & UP3 & DP8 & $\mathrm{CP} 7$ & LB2 & $\mathrm{DP}, \mathrm{CP}, \mathrm{LB}$ & - & $31(\mathrm{~F})$ \\
\hline BS-ECON-36 & UPB & DP8 & $\mathrm{CP} 1$ & LB3 & $\mathrm{DP}, \mathrm{CP}, \mathrm{LB}$ & CP, LB & $22(\mathrm{M})$ \\
\hline BS-SOCIO & UP2 & DPB & $\mathrm{CP7}$ & LB1 & & & \\
\hline BS-SOClO-21 & UP3 & DP3 & $\mathrm{CP} 7$ & LB9 & $\mathrm{DP}$ & - & $26(F)$ \\
\hline BS-SOClO-14 & UP3 & DP8 & $\mathrm{CP} 7$ & LB10 & LB & - & $19(\mathrm{M})$ \\
\hline
\end{tabular}




\section{Discussion}

The models are compact descriptions of a system structure; and they can provide a derivation of the specific predictions from theory that can be tested with the data (Turchin, et al., n. d.). They have the ability to demonstrate understanding through different representations. Depending on the purpose, one can develop different models for the same empirical system. Mehta (2019) explained that model-building or mathematical-modelling uses mathematics to represent, analyze, and make predictions of real-world phenomena.

The analytical stage commenced with the administration of a problem-solving test and a coping-strategy questionnaire from 297 respondents. The results revealed two difficulties in each of the phases of problem-solving, and each respondent encountered at least one of these difficulties in all the phases. Both males and females experienced the same difficulty in all the phases, namely an inability to distinguish the known from the unknown information (U1), which shows partial similarity with the results of Pearce et al. (2013); that is the inability to transform a problem into a mathematical equation (D1), which validates the results of Dela Cruz and Lapinid (2018); as well as the inability to completely perform the working procedure systematically and accurately (C1), which supports the findings of Finney, (n.d.) and Siniguian (2017), and also an inability to start the evaluation of the correctness of the obtained solution (L2), as revealed by Siniguian (2017). The majority of the respondents of the STEM-related academic programs likewise experienced difficulties with U2, D1, C1 and L2; while the majority of the students in the non-STEM related academic programs experienced difficulties in U1, D1, C1 and L2. On the other hand, commonly utilized coping strategies are problem-focused strategies, which reinforces the findings of Carver et al., (1999); Folkman \& Lazarus, 1980, Ghan, (2011); Ader \& Erktin, (2012); Lazarus (1993).

The coping strategies that were elicited reveal that both sexes utilized the same coping strategies in the first three phases of the problem-solving, namely, UP2, DP8 and CP7, respectively. For the looking-back phase, the males preferred to use LB3, an emotion-focused coping strategy, which contradicts the results of Rapson (1990) and Eschenbeck et al. (2002), and LB1 for the females, which is in conflict with the findings of Brougham et al. (2009); Hammermeister \& Burton (2004) and Kaiseler et al. (2012).

In addition, both groups (STEM-related and non-STEM related academic programs) adopted the same set of coping strategies in the different phases, namely, UP2, DP8, CP7 and LB1. Additionally, two coping strategies in the looking-back phase were added, which are LB3 and LB7. The students' responses were triangulated by informal conversation with unstructured interview questions to a selected number of students, and to a few teachers, who handled the identified respondents.

From the identified relationships between and among the variables, two models were developed, namely; Coping Strategy by Sex by Phase Model and Coping Strategy by Academic Program (non STEM-related and Stem-reated) by Phase Model. The effectivity of the models was consequently validated through the 
validation group that comprised 188 respondents. Purposive sampling, where factors like the availability of the respondents, together with their coping strategies that matched those presented in the models developed, were taken into account. From the eight male respondents, three showed a decrease in the frequency of pre-identified difficulty/ies; while five of them totally surpassed all their difficulties. For the 10 sampled female respondents, however, three showed a decrease in the frequency of pre-identified difficulty/ies; while seven of them totally surpassed their difficulties. This information concluded that the models have the ability to address the difficulties of the students in their problem-solving encounters through their coping strategies.

\section{Conclusion}

This study examined the students' difficulties in Mathematical problem-solving and the coping strategies that they applied in response to these difficulties. Although a number of studies have already been implemented to investigate these research variables, this study introduces a different approach of analyzing these, by relating them to factors like students' sexual orientation and academic programs. After the data analysis, the developed models were found to help address the students' difficulties. They were able to either reduce, or totally eradicate the frequency of the students' pre-identified Mathematical problemsolving difficulties. Such findings would input a novel contribution to the literature on educational assessment, specifically in Mathematical problemsolving, since literature and studies dealing with this area are scarce. This study recommends that future research should focus on the extensive identification of the problem-solving difficulties in each of Polya's (1945) problem-solving phases.

A larger scope on the population may be considered. The focus may not only be on the secondary or tertiary education students, rather, the pre-schoolers and the elementary pupils, could be included. The studies show that an interest in numbers and numerical phenomena starts at an early age, like the preschool, or the kindergarten. In their young minds, they should become aware of the fundamental numeric skills and other cognitive foundations that are relevant in learning through mathematics education. Through it, difficulties in problemsolving may be reduced and perhaps may become non-existent as they step up in the educational ladder. Scope in terms of locale may also be considered like provincial or regional with varied dependent variables. Furthermore, future research projects may be conducted on a long-term basis to investigate whether there would be an improvement in the Mathematics problem-solving performance of the students, as their teachers employ the recommended coping strategies presented in the models.

In addition, during this time of pandemic, educators should explore students' problem-solving difficulties and their coping mechanisms in online learning.

\section{Author's Note}

We have no conflicts of interests to disclose.

We acknowledge the Department of Science and Technology-Science Education Institute under the Capacity Building Program in Science and Mathematics, 
University of the Philippines-Open University and Mariano Marcos State

University for the completion of this paper,

We acknowledge John Paul C. Vallente for editing this article.

\section{References}

Ader, E., \& Erktin, E. (2012). Development of the revised form of the coping with mathematics scale. Procedia-Social and Behavioral Sciences, 47(1), 974-980. http://doi.org/10.1016/j.sbspro.2012.06.766

Arfiana, A., \& Wijaya, A. (2018). Problem-solving skills of students of senior high schools and Islamic high schools in Tegal Regency in solving the problem of PISA based on Polya's stage. Jurnal Riset Pendidikan Matematika, 5(2), 211-222. https://journal.uny.ac.id/index.php/jrpm/article/view/15783/11897

Bagasol, A., Corcoro, J., Gallegoes, B., Ramos, M., \& Sagsagat, R. (2015). College students' difficulties in solving Mathematics problems and their coping mechanisms. Unpublished undergraduate thesis. Mariano Marcos State University-College of Arts and Sciences.

Banilower, E., Smith, P., Weiss, I., Malzahn, K., Campbell, K., \& Weis, A. (2013). Report of The 2012 National Survey of Science and Mathematics Education. http://www.horizon-research.com/2012nssme/wpcontent/uploads/2013/02/2012-NSSME-Full-Report1.pdf.

Brougham, R., Zail, C., Mendoza, C., \& Miller, J. (2009). Stress, sex differences, and coping strategies among college students. Current Psychology, 28(2), 85-97. https://link.springer.com/article/10.1007/s12144-009-9047-0.

Cliche, M. (2017). Coping strategies. Center for Studies on Human Stress. https://humanstress.ca/stress/trick-your-stress/steps-to-instant-stressmanagement/

Dela Cruz, J., \& Lapinid, M. (2014). Students' difficulties in translating worded problems into mathematical symbols [Paper presentation]. DLSU Research Congress, De La Salle University, Manila, the Philippines.

Ernst, J. V. (2009). Contextual problem-solving model orientation. Journal of Industrial $\begin{array}{llll}\text { Teacher } & \text { Education, }\end{array}$ https://scholar.lib.vt.edu/ejournals/JITE/v46n2/ernst.html

Eschenbeck, H., Kohlmann, C., \& Lohaus, A. (2007). Gender differences in coping strategies in children and adolescents. Journal of Individual Differences, 28(1), 1826.

https://www.researchgate.net/publication/240218695_Gender_Differences_in_ Coping_Strategies_in_Children_and_Adolescents

Ferguson, D. (1980). The language of Mathematics: How Calculus students cope with it. https://search.proquest.com/docview/302994299/A92A1070E6A7418CPQ/1?a ccountid $=47253$

Finney, R. (n. d.) Research in Problem-Solving: Improving the Progression from Novice to https://physicscourses.colorado.edu/phys4810/phys4810_fa06/4810_readings / finney.pdf

Folkman, S., \& Lazarus, R. S. (1985). If it changes it must be a process: Study of emotion and coping during three stages of a college examination. Journal of Personality and Social Psychology, 48(1), 150-170. https://www.ncbi.nlm.nih.gov/pubmed/2980281

Ganley, C. (2018). Are Boys Better than Girls at Maths? Scientific American. https://www.scientificamerican.com/article/are-boys-better-than-girls-at- 
maths/

Ghana, W. (2011). Coping with Stress: Strategies adopted by Students. Winneba Campus of University of Education, 2(1), 290-299. https://eric.ed.gov/?id=ED528318.

Holahan, C. J., \& Moos, R. H. (1987). Risk, resilience and psychological distress: A longitudinal analysis with adults and children. Journal of Abnormal Psychology, 96, 3-13. https://www.ncbi.nlm.nih.gov/pubmed/3558946.

Houghton, J. D., Wu, J., Godwin, N. C., \& Manz, C. (2012). Effective stress management: A model of emotional intelligence, self-leadership, and student stress coping. Journal of Management Education, 36(2), 220-238.

https://asu.pure.elsevier.com/en/publications/effective-stress-management-amodel-of-emotional-intelligence-sel

Kaiseler, M., Polman, J., \& Nicholls, A. (2012). Gender differences in appraisal and coping: An examination of the situational and dispositional hypothesis. International Journal Sport Psychology. 43, 1-14.

https://www.academia.edu/1822466/Gender_differences_in_Appraisal_and_C oping

Labrague, L. J., Petitte, D. M., Gloe, D., Thomas, L., Papathanasiou, I., \& Tsaras, K. (2016). A literature review on stress and coping strategies in nursing students. Journal of Mental Health, 26(5), 471-480.

http://www.tandfonline.com/doi/full/10.1080/09638237.2016.1244721? src=rec sys

Lockwood, E. (2013). A model of students' combinatorial thinking. The Journal of Mathematical Behavior, 32(2), 251-265. https://www.sciencedirect.com/science/article/pii/S0732312313000230

Lopez, L. (2008). Helping at-risk students solve mathematical word problems through the use of direct instruction and problem-solving strategies. Master's Thesis (Open Access). Electronic Theses and Dissertations. University of Central Florida. http:/ / stars.library.ucf.edu/cgi/ viewcontent.cgi?article $=4668 \&$ context $=$ etd

Okoro, E. (2018). Assessment of stress-related issues and coping mechanisms among college students. Unpublished Master's Thesis. Minnesota State University. https:/ / cornerstone.lib.mnsu.edu/cgi/viewcontent.cgi?article=1823\&context=et ds

Nikmah, L., Juandi, D., \& Prabawanto, S. (2019). Students' difficulties in solving mathematical problems based on ESD objectives. Journal of Physics: Conference Series, $\quad 1157(3) . \quad$ https://iopscience.iop.org/article/10.1088/17426596/1157/3/032116/meta

Pearce, D., Skinner, K., Bruun, F., \& Lopez-Mohler, C. (2013). What teachers say about student difficulties in solving mathematical word problems in Grades 2-5. International Electronic Journal of Mathematics Education, 8(1), 3-19. https://www.researchgate.net/publication/286608143_What_teachers_say_abo ut_student_difficulties in_solving_mathematical_word_problems_in_grades_2-5

Polya, G. (1945). How to solve it: A new aspect of mathematical method. Princeton, USA, Princeton University Press. http://www.math.wichita.edu/history/men/polya.html

Quan, S. F. (2015). The impact of stressful situations on Mathematics anxiety and Mathematics performance. Unpublished Dissertation. Teacher's College, Columbia University. https://search.proquest.com/docview/1686872168/7A18ADA909F64C4DPQ/1 ?accountid $=47253$

Rapson, K. E. (1990). Relationship and achievement stressors: Gender differences in appraisals, coping and outcomes. Unpublished Dissertation. Virginia Consortium for Professional Psychology. 
https:// search.proquest.com/dissertations/docview/303907001/A76AEBB97F4 $7441 \mathrm{DPQ} / 31$ ?accountid $=47253$

Reddy, M., \& Panacharoensawad, B. (2017). Students 'problem-solving difficulties and implications in Physics: An empirical study on influencing factors. Journal of Education and Practice, 8(14), 59-62.

Rioveros, J. A. (2013). Finding Relations on Conceptual Knowledge, Science Process Skills and Coping Strategies of Students in the K to 12 Curriculum (Unpublished Master's Thesis). Philippine Normal University, Manila.

Ronda, R. A. (2011). DepEd: Achievement rates of students declining. Philstar Global. https://www.philstar.com/headlines/2011/05/26/689518/depedachievement-rates-students-declining.

Ryan, K. (2013). How problem-focused and emotion-focused coping affects college students' perceived stress and life satisfaction.

https://pdfs.semanticscholar.org/a2da/542c75c6b1d6b48f9d8320db79484896b2 2d.pdf

Sawrey, B. A. (1990). Concept learning versus problem-solving: Revisited. Journal of Chemical Education. 67(3), 253-254. https://eric.ed.gov/?id=EJ409410

Siniguian, M. (2017). Students' difficulties in solving mathematical problems. International Journal of Advanced Research in Engineering and Applied Sciences, 6(2). 1-12. www.academia.edu

Sukoriyanto, Nusantra, T., Subanji, \& Chandra, D. (2016). Students' Errors in Solving the Permutation and Combination Problems, based on the Problem-Solving Steps of Polya. International Education Studies, 9(2). https://files.eric.ed.gov/fulltext/EJ1090195.pdf

Sultan, L. P. (2014). Challenges Encountered by Students in Solving Algebra Word Problems. An Undergraduate Thesis. College of Education, University of Southern Mindanao, Cotabato City.

Tamres, L., Janicki, D., \& Helgeson, V. (2002). Sex differences in coping behavior: A metaanalytic review and an examination of relative coping. Personality and Social Psychology Review, 6(1), 2-30. 